\title{
Rock Magnetism of Late Cretaceous to Middle Eocene Strata in the Lesser Himalaya, Western Nepal: Inferences Regarding the Paleoenvironment
}

\author{
Dhan Bahadur Khatri ${ }^{1,2}$, Weilin Zhang ${ }^{1 *}$, Xiaomin Fang ${ }^{1,2}$, Qingquan Meng $^{3}$, Tao Zhang $^{3}$, \\ Dawen Zhang $^{4}$ and Khum N. Paudayal ${ }^{5}$
}

${ }^{1}$ State Key Laboratory of Tibetan Plateau Earth System, Resources and Environment (TPESRE), Institute of Tibetan Plateau Research, Chinese Academy of Sciences, Beijing, China, ${ }^{2}$ University of Chinese Academy of Sciences, Beijing, China, ${ }^{3}$ School of Earth Sciences, Key Laboratory of Western China's Mineral Resources of Gansu Province, Lanzhou University, Lanzhou, China, ${ }^{4}$ College of Tourism and Environmental Resource, Zaozhuang University, Zaozhuang, China, ${ }^{5}$ Central Department of Geology, Tribhuvan University, Kirtipur, Nepal

OPEN ACCESS

Edited by:

Yunfa Miao,

Northwest Institute of ECOEnvironment and Resources (CAS),

China

Reviewed by:

Dongliang Liu,

Chinese Academy of Geological

Sciences (CAGS), China

Yougui Song,

Institute of Earth Environment (CAS),

China

*Correspondence: Weilin Zhang

zhangwl@itpcas.ac.cn

Specialty section:

This article was submitted to Structural Geology and Tectonics,

a section of the journal

Frontiers in Earth Science

Received: 19 July 2021 Accepted: 22 September 2021

Published: 05 October 2021

Citation:

Khatri $D B$, Zhang $W$, Fang $X$, Meng $Q$,

Zhang $T$, Zhang $D$ and Paudayal KN

(2021) Rock Magnetism of Late

Cretaceous to Middle Eocene Strata in the Lesser Himalaya, Western Nepal: Inferences Regarding

the Paleoenvironment.

Front. Earth Sci. 9:744063.

doi: 10.3389/feart.2021.744063
The growth of the southern piedmont of the Himalayan boundary and its depositional setting has changed since uplift of the Himalaya due to continental Indian-Eurasian collision, which has resulted in variation in magnetic minerals in marine- and terrestrialfacies sediments. In this paper, we utilize rock magnetism data from the late Cretaceous to middle Eocene strata, including the Amile and Bhainskati formations from the Lesser Himalaya (western Nepal), to understand the mechanism controlling magnetic susceptibility $(\chi)$. The active tectonics strongly influenced saturation isothermal remanent magnetization (SIRM), HIRM, and hysteresis loops, forming both lowcoercivity minerals in sediments with low $\chi$ from the terrestrial facies (zones I, IIIA, and $V$ ) and high-coercivity minerals in the sediments with high $\chi$ from the marine facies (zones II, IIIB and IV). Thermomagnetic $\kappa-T$ curves and frequency-dependent $\chi(\chi \mathrm{fd} \%)$ values show that sediments with low $\chi$ and high $\chi$ carry magnetite with coarse non-superparamagnetic (SP) grains and hematite with SP grains, respectively. Comparing the $\chi$ data with the lithologic, sedimentary environments, geomorphic features, and sea level data, we propose that low $\chi$ values were mainly produced by an increase in terrigenous detrital influx during the regression period of the Tethys Sea, while high $\chi$ values formed in marine sediments, which prompted the appearance of ferromagnetic-antiferromagnetic and paramagnetic minerals during the transgression of the Tethys Sea.

Keywords: rock magnetism, Cretaceous to Eocene strata, paleoenvironment, transgression and regression, Lesser Himalaya

\section{INTRODUCTION}

The Himalayan orogeny and tectonic stress produced the existing Himalayan arc as a result of the Indian-Eurasian collision since the late Cretaceous time (Beck et al., 1995). This has attracted the attention of various scientists to study its effect on geomorphological features (Molnar and Tapponnier, 1975), provenance (Garzanti, 1999; DeCelles et al., 2004; DeCelles et al., 2014), climate (Ghosh et al., 1995), environment (Bosboom et al., 2014) and ecology (Smith et al., 2015). In Nepal, some paleomagnetic studies have been carried out in the Siwalik (Tokuoka 
et al., 1986; Gautam and Appel, 1994; Gautam et al., 1995; Gautam and Pant, 1996; Gautam and Fujiwara, 2000; Gautam, 2008; Ojha et al., 2009), Lesser, Higher and Tethyan Himalaya (Yoshida and Sakai, 1984; Appel et al., 1991; Pant et al., 1992; Crouzet et al., 2001; Gautam et al., 2011). The Tansen area, which is located at the front of the Lesser Himalaya, incorporates both marine and terrestrial sediments since the continental collision and uplift of the Himalaya. It acts as a remarkable area for reconstructing the tectonic and climatic evolution before and after the collision. Various studies related to detrital geochronology and geochemistry, lithological transitions, flora and faunal fossils have been reported from this region (Sakai, 1983; Sakai, 1984; Kimura et al., 1985; Matsumaru and Sakai, 1989; Sah and Schleich, 1990; DeCelles et al., 2004), showing diverse opinions on the paleoenvironmental condition. Generally, four distinctive views can be perceived on the paleoenvironment changes as 1) the humid climate prevailed during Cretaceous to Eocene (Neupane and Zhao, 2018; Neupane et al., 2021), 2) there was a paleoenvironmental transition from the pteridophytes dominated wet and humid environment during late Cretaceous (Mohabey et al., 1993; Srivastava, 2011; Prasad et al., 2018) to more humid environment in the entire Eocene revealed by evergreen broad-leaved forest forming coal and carbonaceous shale (Mehrotra, 2003; Srivastava, 2011; Shukla et al., 2014; Spicer et al., 2014; Samant et al., 2020), 3) the paleoclimate during Cretaceous to Eocene had been affected by the Tethys Sea and the Himalayan tectonic uplift rather than the global climate change (Bosboom et al., 2011; Licht et al., 2013; Licht et al., 2014), and 4) the Inter-tropical Convergence Zone (ITCZ) had driven the Eocene monsoon climate (Boos and Kuang, 2010; Spicer et al., 2016). The poor preservation of late Cretaceous marine and early Cenozoic terrestrial sequences in South Asia has been the main factor causing these debates. The Palpa section in this area consists of a late Cretaceous-Paleocene (so called Amile Formation) to middle Eocene (called as Bhainskati Formation) sequence of both marine and terrestrial sediments. Their respective ages were constrained by $\mathrm{U}-\mathrm{Pb}$ detrital zircon ages, $\mathrm{Nd}$ isotope analyses and trace element compositions (Robinson et al., 2001; Neupane et al., 2017; Bhandari et al., 2019) and fossil records (Sakai, 1983; Matsumaru and Sakai, 1989). The rock magnetic study has been rarely reported from this area (Gautam, 1989a, b) and is expected to effectively diagnose the paleoenvironmental changes in the Lesser Himalaya, western Nepal.

The uplift of the Himalaya-Tibetan Plateau after the IndianEurasian collision has affected the provenance and environmental settings in this region. In addition, the transgression and regression of the Tethys sea within this region also caused the change in depositional settings (either terrestrial or marine setting). The depositional processes have been widely investigated through the rock magnetic properties of sedimentary sequences in the recent years (Verosub and Roberts, 1995; Liu et al., 2012). The magnetic parameters have been also applied for obtaining better discrimination of lithological units such as marine limestone or mudstone and continental clastic rock (Murdock et al., 2013). The Palpa section, on the southern piedmont of the Himalaya records abundant environmental and tectonic information. It provides an excellent opportunity to explore the paleoenvironment through the study of rock magnetic analysis. In this paper, we examine detailed rock magnetic analyses from the Palpa section in the Tansen area to identify the depositional setting that most likely controlled the magnetic susceptibility $(\chi)$ variation and make an initial attempt to gain insights into the relationship between the depositional environment and the tectonic uplift during and after the Indian-Eurasian collision.

\section{GEOLOGICAL AND GEOGRAPHICAL SETTING}

The Indian-Eurasian collision results in the development of four different tectonostratigraphic units (Figure 1A). The northern Tethys Himalayan Sequence (Neoproterozoic through Cenozoic) is mainly composed of sedimentary rocks with numerous fossiliferous horizons (Stöcklin, 1980; Garzanti and Frette, 1991; Yin and Harrison, 2000; Guillot et al., 2008; Najman et al., 2017). In its south, the high-grade metasedimentary rocks of the Higher or Greater Himalayan Sequence (Neoproterozoic through Cambrian) is thrust southward along the Main Central Thrust (MCT) on the uppermost part of the Lesser Himalayan Sequence (Paleoproterozoic to Paleozoic) (Parrish and Hodges, 1996; DeCelles et al., 2000; Martin, 2017). Furthermore, the weakly metamorphosed Indian continental crust and sedimentary rocks of the Lesser Himalayan Sequence (Valdiya, 1980; Sakai, 1985; Parrish and Hodges, 1996; Upreti, 1999; DeCelles et al., 2000; Martin et al., 2011) are separated by the Main Boundary Thrust (MBT) in the south. The southernmost part consist of marginal deposits eroded from the higher mountain belts, deposited in the foreland basin as the Siwalik (or Churia zone) or Sub-Himalayan Sequence (Paleogene and Neogene), and now lie above the Main Frontal Thrust (MFT) with recent alluvial deposits of the IndoGangetic plain (Gansser, 1964; Stöcklin, 1980; DeCelles et al., 1998; White et al., 2001; Najman et al., 2005; van der Beek et al., 2006; Yin, 2006; Ojha et al., 2009). In Nepal, the late Permian to Eocene sediments (called the Gondwana System) typically contains both marine facies, including fossiliferous argillaceous limestones and siltstone/sandstone with molluscs, foraminifers, coral and vertebrate fossils, and terrestrial facies, including ferruginous quartz arenite, conglomeratic quartz arenite, glacial diamictite, interbedded sandstone, and shale. These lithostratigraphic units are sparsely distributed in the Barahachhetra and Katari areas, Tansen, Tulsipur, and the Birendranagar areas extending from east to west, indicating the existence of scattered depositional basins with variable thicknesses. The tectonic stress on the depositional basins (Gondwana System) in the Lesser Himalaya of Nepal has resulted in the formation of klippes (such as the Palpa Klippe).

The study area lies within the region $27^{\circ} 42^{\prime} 0^{\prime \prime} \mathrm{N}$ to $27^{\circ} 52^{\prime} 0^{\prime \prime} \mathrm{N}$ and $83^{\circ} 27^{\prime} 0^{\prime \prime} \mathrm{E}$ to $83^{\circ} 33^{\prime} 0^{\prime \prime} \mathrm{E}$ in the Tansen area (Palpa district) in the northern part of the Siwalik zone and to the north of the MBT (Figure 1B,C,D). The sampling sites along the so-called Palpa section are located near Charchare village along the Bhaiskatta Khola (the local term for the river is Khola) flowing south of the Tansen city. In the Tansen area, the Kali Gandaki Supergroup (KGS) comprises bioturbated sediments to low-grade 

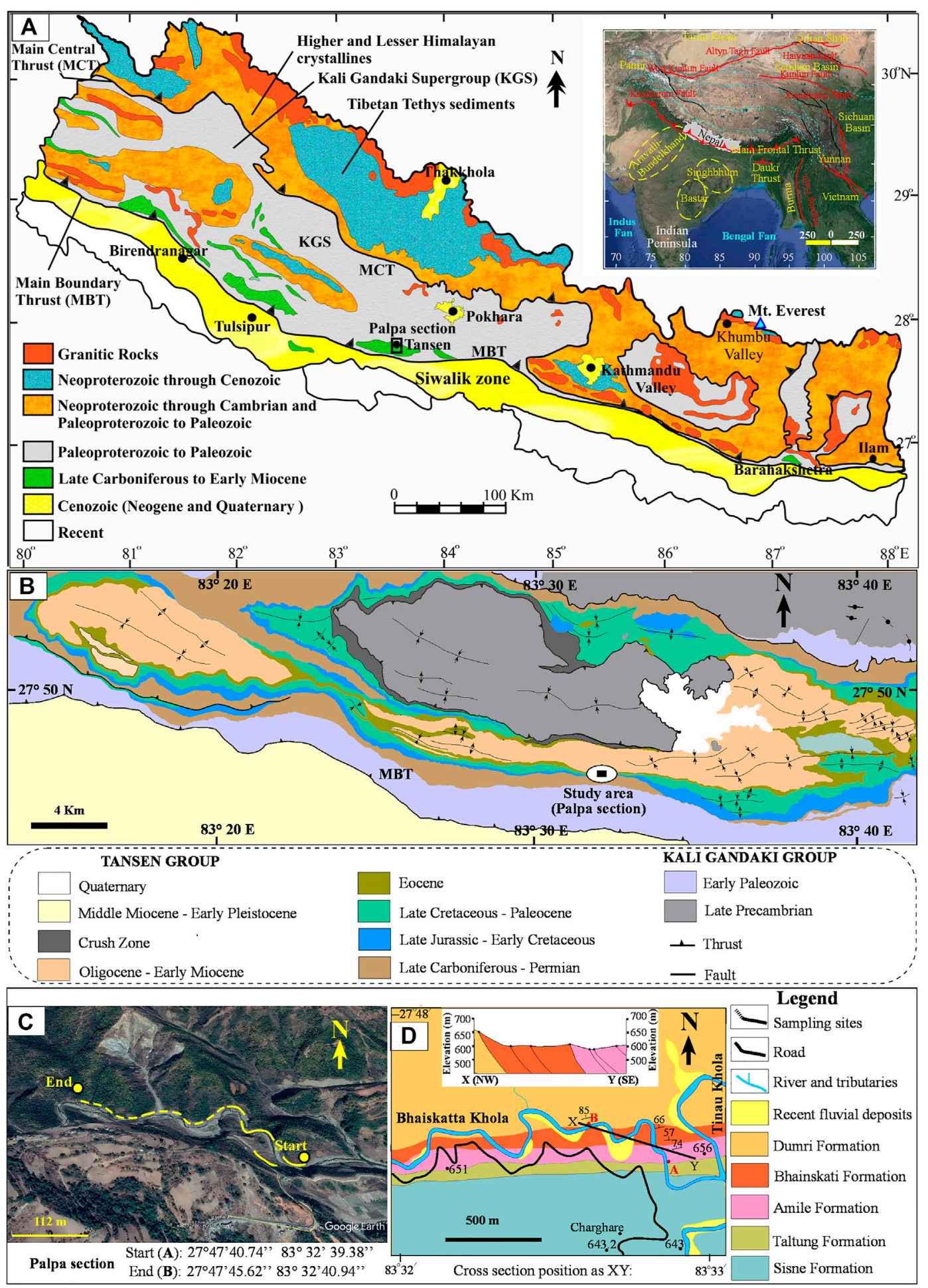

FIGURE 1 | Geological framework of Nepal. (A) Simplified geological map of the Nepal Himalaya showing the location of the study area (Palpa section) in the Tansen area, modified after Khatri et al. (2017). (B) Detailed geological map of the western Nepal. The black rectangular box indicates the Palpa section, modified after Sakai (1983), Sakai (1984), Dhital (2015). (C) Google map (http://earth.google.com/) showing the sampling route in the Bhaiskatta Khola from $27^{\circ} 47^{\prime} 40.74^{\prime \prime} 83^{\circ} 32^{\prime} 39.38^{\prime \prime}$ to $27^{\circ} 47^{\prime} 45.62^{\prime \prime} 83^{\circ} 32^{\prime} 40.94$ ". (D) Detailed geological map of the study area and the cross-section for the samples profile showing the late Cretaceous to Oligoceneearly Miocene strata. 


\section{Photographs for the lithologies of the Late Cretaceous to} middle Eocene strata

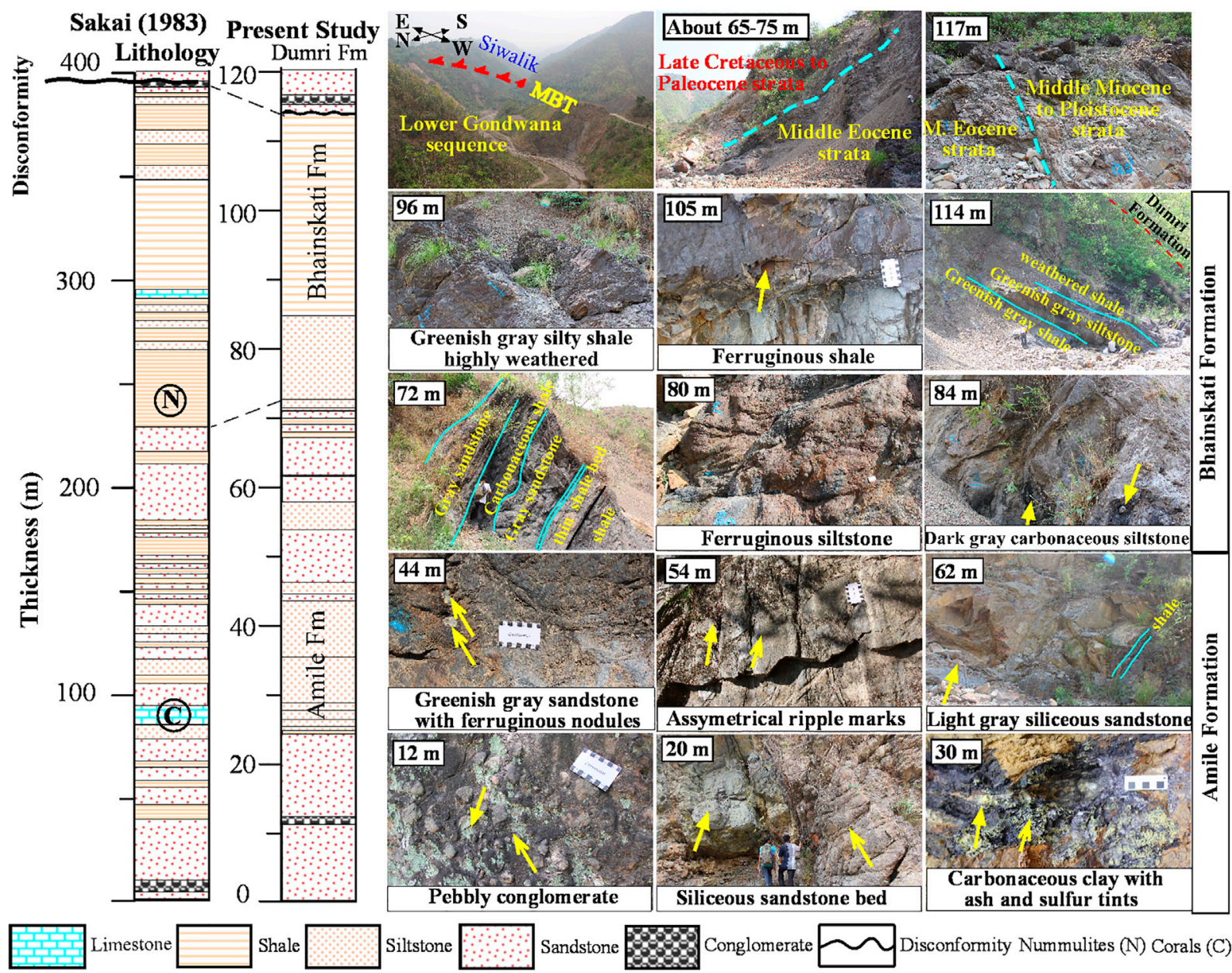

FIGURE 2 | Lithostratigraphic correlation of the Amile (late Cretaceous-Paleocene) and Bhainskati (middle Eocene) formations between the present and previous studies. The field photographs from 12 to $62 \mathrm{~m}$ represent Amile Formation and from 72 to 114 m represent Bhainskati Formation. The boundary between late Cretaceous-Paleocene and middle Eocene strata exists nearly at 65-75 m. In addition, the boundary between middle Eocene and middle Miocene to Pleistocene strata exists nearly at $117 \mathrm{~m}$. These photographs show the distinct lithologies from both formations in the Palpa section.

metamorphic rock, argillaceous, carbonate rocks with stromatolites of late Precambrian to early Paleozoic age (Sakai, 1984). The Tansen Group, assigned to the late Carboniferous to early Miocene age by paleontology and stratigraphic position (Sakai, 1983), disconformably overlies the KGS and forms a large synclinorium with a klippe (Figure 1B). Lithostratigraphically, the Tansen Group is divided from bottom to top into the Sisne Formation with mudstone intercalated sandstone, and conglomerate; the Taltung Formation with silty shale, sandstone, and conglomerate; the Amile Formation with quartz sandstone with thick interlayers of black shale and limestone; the Bhainskati Formation with shales and limestone; and the Dumri Formation with sandstone and conglomerate interbedded with shale (Sakai, 1983; Sakai, 1984; Sakai, 1989). The Amile Formation typically consists of terrestrial and marine facies. The lower and upper parts of the Amile Formation are terrestrial facies composed of ferruginous quartz arenite, conglomeratic quartz arenite, and interbedded sandstone and shale, whereas the middle part is marine facies composed of argillaceous limestone and siltstone/sandstone yielding molluscs, echinoids, corals, and vertebrate fossils. In contrast, the marine Bhainskati Formation is characterized by the predominance of fossiliferous black and green shales yielding molluscs, foraminifers, and vertebrate fossils. It also includes bioturbation with thin beds of limestone and oolitic hematic mottles (Sakai, 1983; Sakai, 1984) with hematitic oxisol layers (DeCelles et al., 1998).

\section{SAMPLING AND LABORATORY PROCEDURES}

The study area covers late Mesozoic to early Paleogene rocks lying in the southwestern part of the Lesser Himalaya of Nepal, 
including the Amile, Bhainskati, and partly Dumri formations (Figure 2). In the study area, 120 samples were collected (Figure 1C) with a portable petrol-powered drill at an interval of $1 \mathrm{~m}$. Later, these core samples were cut into standard-size of $2.2 \mathrm{~cm}$ diameter and $2.5 \mathrm{~cm}$ in length. The Amile Formation in the study area is approximately $72 \mathrm{~m}$ thick and is composed mainly of shale, fine-grained to medium-grained siliceous sandstone, and pebble conglomerate, and occasionally contains iron nodules and asymmetrical ripple marks. The Bhainskati Formation is approximately $41 \mathrm{~m}$ thick and composed of light gray, dark gray, green shale, and siltstone with no fossiliferous horizons. The Dumri Formation is composed of gray sandstone, gray-red intraformational conglomerate, and gray siliceous sandstone and is approximately $7 \mathrm{~m}$ thick (Figure 2).

All the sampled specimens of the Palpa section were measured by the AGICO MFK1-FA multifunction Kappabridge to determine low- and high-frequency magnetic susceptibility ranging from 976 to $1,561 \mathrm{~Hz}$. The mass-specific susceptibility $(\chi)$ was measured at these frequencies and the $\chi \mathrm{fd} \%$ was calculated as $\chi \mathrm{fd} \%=\left(\chi_{976 \mathrm{~Hz}}-\chi_{1561 \mathrm{~Hz}}\right) / \chi_{976 \mathrm{~Hz}} \times 100 \%$. The anhysteretic remanent magnetization (ARM) process was carried out in a $100 \mathrm{mT}$ peak alternating field and a superimposed $0.05 \mathrm{mT}$ direct current biasing field with a D2000 alternating demagnetizer, and later the susceptibility of $\mathrm{ARM}(\chi \mathrm{ARM})$ was calculated as ARM/0.05 mT. The saturation isothermal remanent magnetization (SIRM) process was performed in an IM-10-30 pulse magnetizer with a 1,000 mT field. In addition, the "hard" isothermal remanent magnetization (HIRM) was calculated using the formula HIRM = (SIRM + IRM300mT)/2 (Thompson and Oldfield, 1986).

Altogether, 46 samples of shales, siltstones, and sandstones were measured for diffuse reflectance spectroscopy (DRS). As it shows a high sensitivity to the concentration of iron oxides (Scheinost et al., 1998; Torrent and Barrón, 2002). The data obtained from a Purkinje General TU1901 UV-Vis spectrophotometer with a reflectance sphere from 360 to $850 \mathrm{~nm}$ at $1 \mathrm{~nm}$ intervals were processed by the first derivative to reveal the hematite content (Zan et al., 2018). The determination of redness (percent reflectance in the red color band) offers an additional quantitative view of one aspect of sediment color (Ji et al., 2005). Redness percent was calculated as red area $(630-700 \mathrm{~nm}) /$ peak area $(400-700 \mathrm{~nm}) \times 100$. Similarly, eight representative samples in powdered form with a mass of $\sim 0.2 \mathrm{~g}$ were chosen for thermomagnetic analysis of magnetic susceptibility, each measured by using a CS- 4 apparatus in an argon atmosphere coupled to a AGICO MFK1-FA multifunction Kappabridge, to prevent oxidation during heating from room temperature to $\sim 700^{\circ} \mathrm{C}$ and later cooled to room temperature. The temperature rate was used as $12^{\circ} \mathrm{C} / \mathrm{min}$ (medium-type), with an approximate duration of $2 \mathrm{~h}$. These representative samples were further measured by a Lakeshore Model 8,600 vibrating sample magnetometer (VSM) to determine the magnetic parameters, such as induced magnetizations [hysteresis parameters-hysteresis loops, saturation magnetization (Ms), saturation remanent magnetization (Mrs), and coercivity (Hc)] and remanent magnetizations in variable magnetizing fields. An alternating gradient force of a magnetometer was used for hysteresis loops analysis and pulse magnetizer for Isothermal Remanent Magnetizations (IRMs), with a maximum field of 1,000 mT. Magnetic coercivity components acquired from IRM acquisition measurements were achieved using the MAX Unmix application (Maxbauer et al., 2016). These experiments were carried out in the Key Laboratory at the Institute of Tibetan Plateau Research, Chinese Academy of Sciences, Beijing, China.

\section{RESULTS}

\section{$\chi, \chi f d \%, \chi A R M$, Saturation Isothermal Remanent Magnetization, High Field Isothermal Remanent Magnetization and Diffuse Reflectance Spectroscopy Results}

On the basis of $\chi$, frequency-dependent $\chi(\chi \mathrm{fd} \%), \chi \mathrm{ARM}, \mathrm{SIRM}$, high field isothermal remanent magnetization (HIRM), redness, hematite content, and lithology, the Palpa section can be divided into five-rock magnetic zones (Figure 3). These magnetic zonations cover both terrestrial and marine deposits. The zone I (0-30 m), zone IIIA (47-72 $\mathrm{m})$, and zone V (114-120 m) are defined as terrestrial deposits, and zone II (31-46 m), zone IIIB (73-98 m), and zone IV (99-113 m), as marine deposits (Figures $2,3)$. The $\chi$ values for zone I, IIIA and V range from $-0.10 \times$ $10^{-8} \mathrm{~m}^{3} \mathrm{~kg}^{-1}$ to $15.41 \times 10^{-8} \mathrm{~m}^{3} \mathrm{~kg}^{-1}$, from $-0.12 \times 10^{-8} \mathrm{~m}^{3} \mathrm{~kg}^{-1}$ to $18.05 \times 10^{-8} \mathrm{~m}^{3} \mathrm{~kg}^{-1}$, and from $3.17 \times 10^{-8} \mathrm{~m}^{3} \mathrm{~kg}^{-1}$ to $8.53 \times$ $10^{-8} \mathrm{~m}^{3} \mathrm{~kg}^{-1}$, respectively and their respective mean are $3.25 \times$ $10^{-8} \mathrm{~m}^{3} \mathrm{~kg}^{-1}, 6.29 \times 10^{-8} \mathrm{~m}^{3} \mathrm{~kg}^{-1}, 6.29 \times 10^{-8} \mathrm{~m}^{3} \mathrm{~kg}^{-1}$ and $5.73 \times$ $10^{-8} \mathrm{~m}^{3} \mathrm{~kg}^{-1}$. The sandwich of some nonferromagnetic phases, such as coal-bearing shale and thin carbonaceous layers cause a sudden drop in $\chi$ in the siltstone and/or sandstone layers. In contrast, $\chi \mathrm{fd} \%$ is always lower in samples with high $\chi$, SIRM, and HIRM values. The $\chi \mathrm{ARM}$ values are almost 1 or 2 times higher in the terrestrial facies than in the marine facies. In addition, the $\chi$ values for zone II, IIIB and IV range from $20.08 \times 10^{-8} \mathrm{~m}^{3} \mathrm{~kg}^{-1}$ to $65.81 \times 10^{-8} \mathrm{~m}^{3} \mathrm{~kg}^{-1}$, from $0.08 \times 10^{-8} \mathrm{~m}^{3} \mathrm{~kg}^{-1}$ to $23.87 \times$ $10^{-8} \mathrm{~m}^{3} \mathrm{~kg}^{-1}$ and from $7.72 \times 10^{-8} \mathrm{~m}^{3} \mathrm{~kg}^{-1}$ to $77.94 \times$ $10^{-8} \mathrm{~m}^{3} \mathrm{~kg}^{-1}$, respectively, and their respective mean are $38.26 \times 10^{-8} \mathrm{~m}^{3} \mathrm{~kg}^{-1}, 8.99 \times 10^{-8} \mathrm{~m}^{3} \mathrm{~kg}^{-1}$ and $26.26 \times$ $10^{-8} \mathrm{~m}^{3} \mathrm{~kg}^{-1}$. A small $\chi$ peak in the zone I occur due to the presence of ferruginous matter in the sandstone.

Noticeable sharp changes in $\chi$, SIRM, and HIRM occur in the fine sediments of the marine facies, and low values usually occur in the coarser sediments of the terrestrial facies. The SIRM and HIRM are consistent with the $\chi$, and the highest peaks are $21.01 \times$ $10^{-8} \mathrm{~m}^{3} \mathrm{~kg}^{-1}$ and $26.42 \times 10^{-8} \mathrm{~m}^{3} \mathrm{~kg}^{-1}$, respectively, at $41 \mathrm{~m}$. The redness and hematite content show trends similar to those of the rock magnetic parameters (Figure 3), which are almost consistent with the magnetization and hysteresis parameters of Figure 4. As $\chi, \chi \mathrm{fd} \%, \chi \mathrm{ARM}$, and SIRM were investigated for identifying variable magnetic mineral concentrations, further investigation

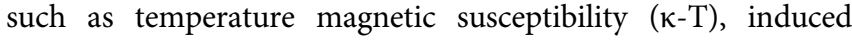
magnetizations (hysteresis loops), and IRM curves from rock samples in variable magnetizing fields are also discussed below for detailed magnetic mineralogy of the sediments that enhance paleoenvironmental study. 


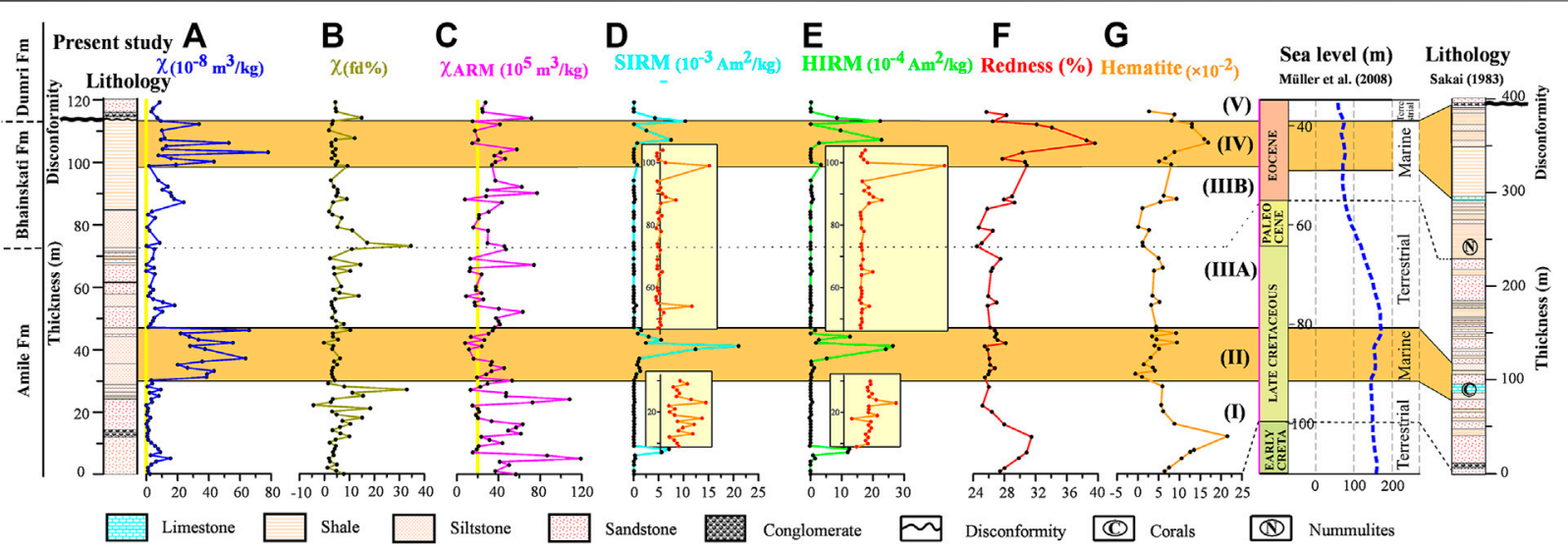

FIGURE 3 | (A-G) Lithology, $\chi, \chi f d \%, \chi A R M$, SIRM, HIRM, redness (\%) and diffuse reflectance spectroscopy-determined hematite content (FDV568 nm), and (H) Their comparison with global sea level (Müller et al., 2008) and correlation for the Palpa section, modified after Sakai (1983). The zones I (0-30 m), IIIA (47-72 m), and V (114-120 m) are defined as terrestrial deposits and zones II (31-46 m), IIIB (73-98 m) and IV (99-113 m) as marine deposits. Note that the orange color represents marine and white represents the terrestrial environment.

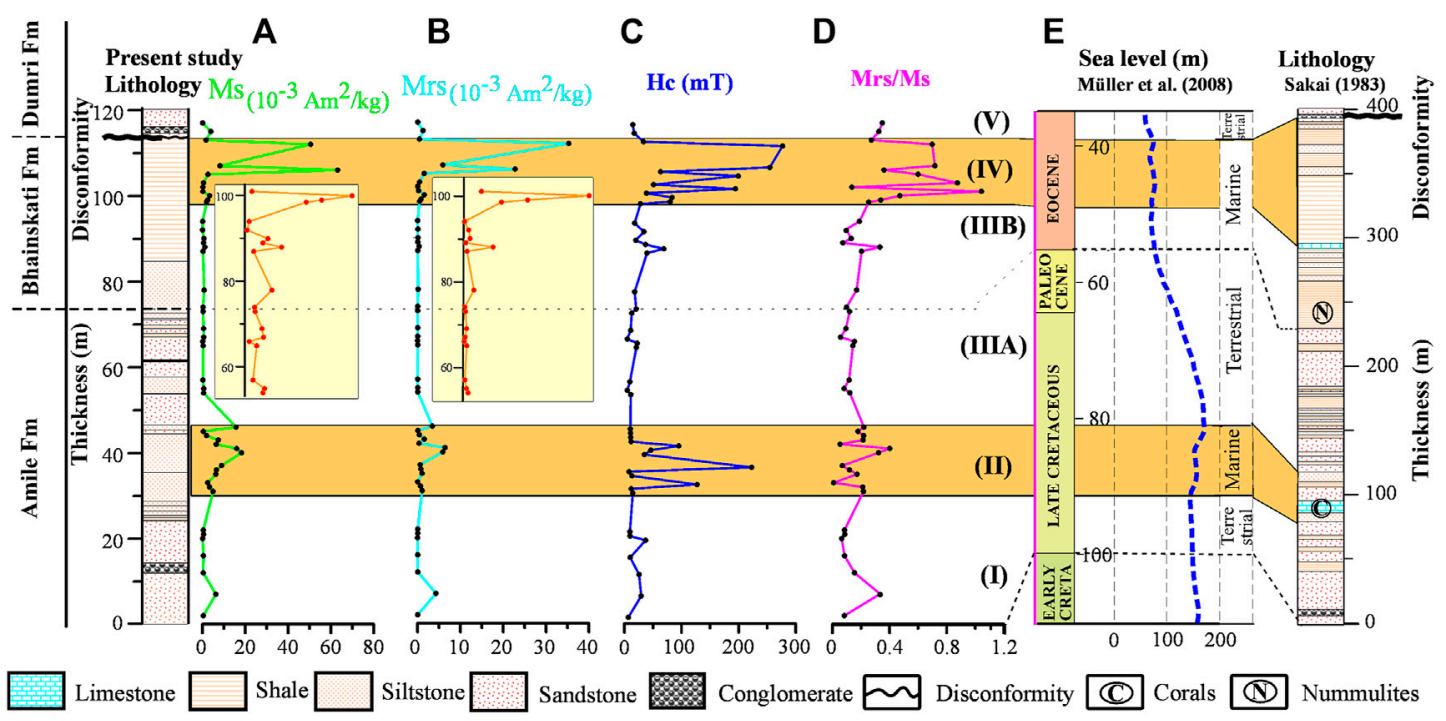

FIGURE 4 | Lithology and hysteresis parameters (Ms, Mrs, Hc and Mrs/Ms) variations of the late Cretaceous to middle Eocene strata in the Palpa section. The samples within the marine regime show greater peaks of hysteresis parameters as compared to the terrestrial regime. The change in sea level condition may have affected the development of these peaks.

\section{High-Temperature Magnetic Susceptibility ( $\kappa-T$ Curves)}

Figure 5 displays each of the $\kappa-\mathrm{T}$ curves with a noticeable decrease near $580^{\circ} \mathrm{C}$, which suggests the ample occurrence of magnetite in the sediments. A subsequent drop in heating curves (Figures $\mathbf{5 A - C}$ ) until around $700^{\circ} \mathrm{C}$ in siliceous and silty sandstone samples, indicates magnetite as the dominant magnetic carrier. But, the heating curve of the sample at $2 \mathrm{~m}$ (Figure 5A), possibly implies a maghemite-like phase (drop at about $350^{\circ} \mathrm{C}$ ). There is evidence of the neoformation of magnetite in most samples (Figures $\mathbf{5 B}-\mathbf{F}, \mathbf{H}$ ), either by reduction due to burning of organic matter and/or neoformation of minor ferromagnetic phase from iron-bearing silicates or possibly Fe-bearing paramagnetic minerals (most likely iron sulfides such as pyrite and greigite). In these samples, the heating curve firstly decreases steadily to $300^{\circ} \mathrm{C}$ and then increases between $350^{\circ} \mathrm{C}$ and $520^{\circ} \mathrm{C}$. Meanwhile, the heating curve progressively decreases nearly to zero at $690^{\circ} \mathrm{C}$ in the siltstone and shale (Figures 5D-H), inferring some hematite as a magnetic carrier (Shouyun et al., 2002; Kruiver et al., 2003; Ao et al., 2010). Thus, both magnetite and hematite act as a major magnetic carrier in these samples. 

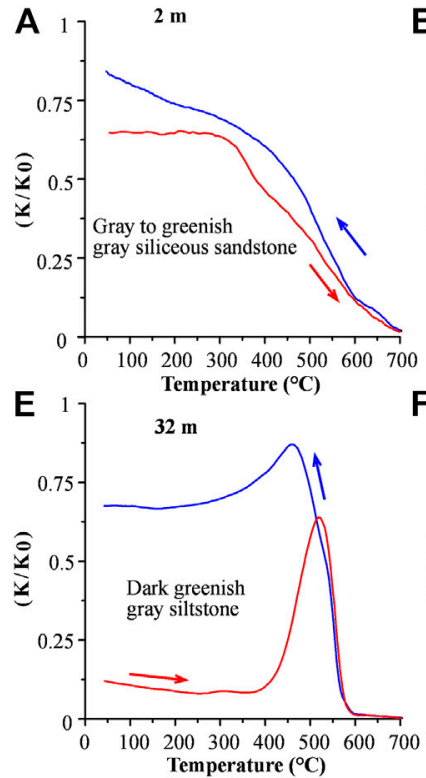
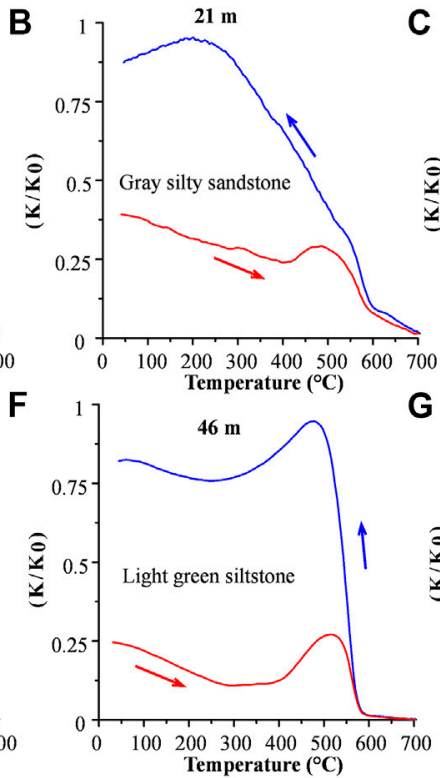
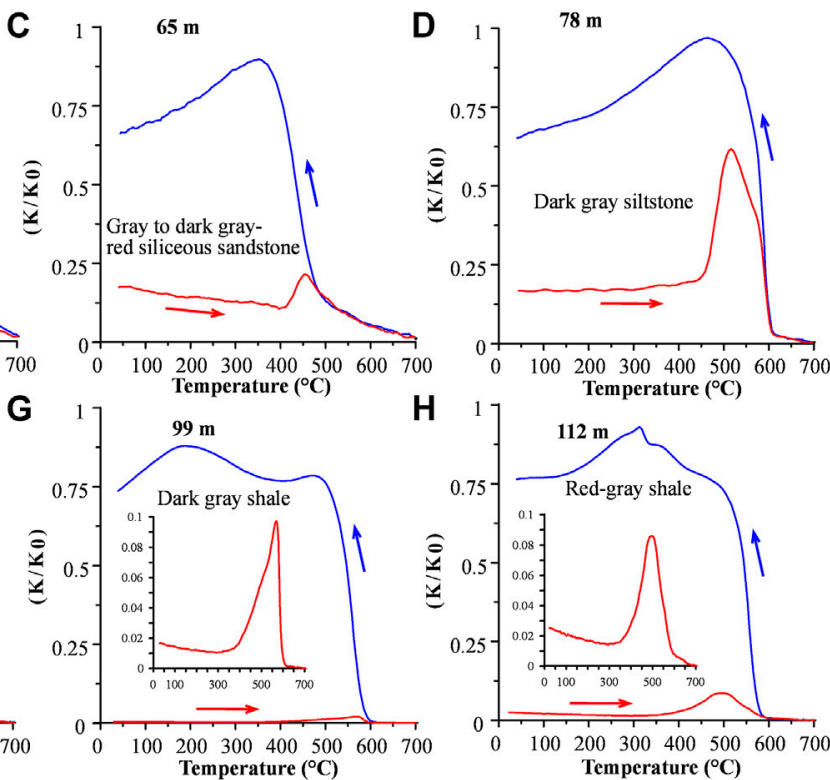

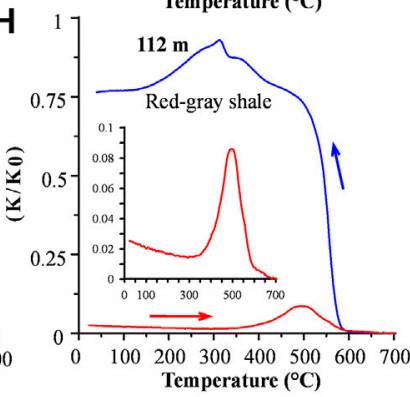

FIGURE 5|Representative temperature-dependent susceptibility curves from selected samples at various horizons of the Palpa section. The samples with a low $\chi$ value are shown in (A-D) and a high $\chi$ value in (E-H). Note: Heating and cooling cycles are indicated by red and blue lines, respectively.

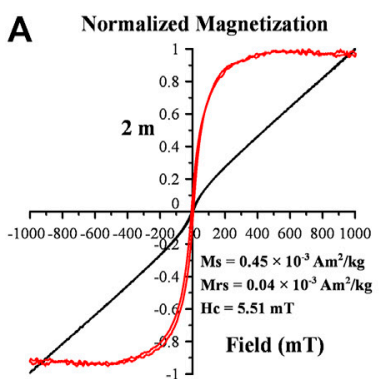

E Normalized Magnetization

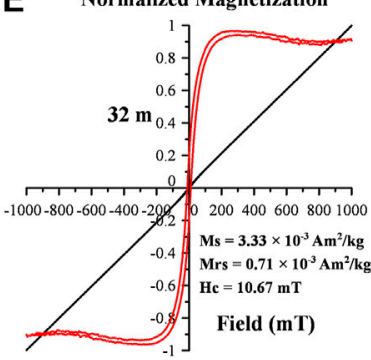

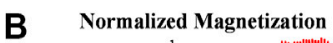

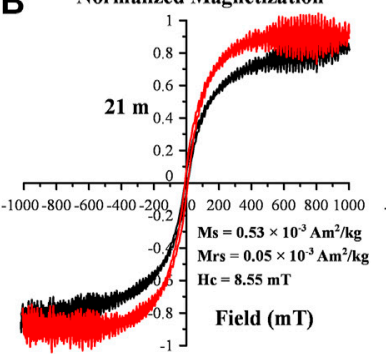

F

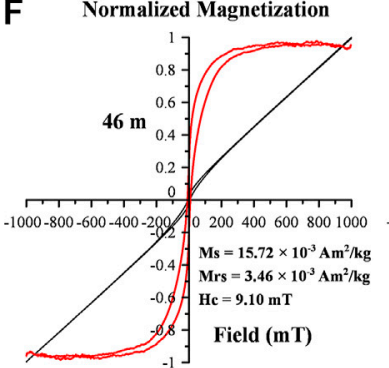

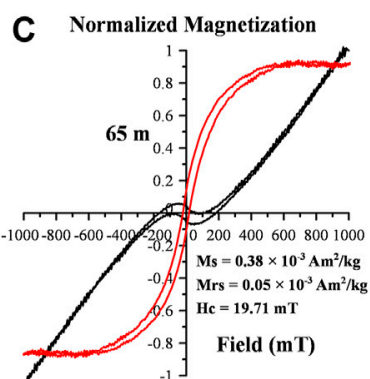

G Normalized Magnetization

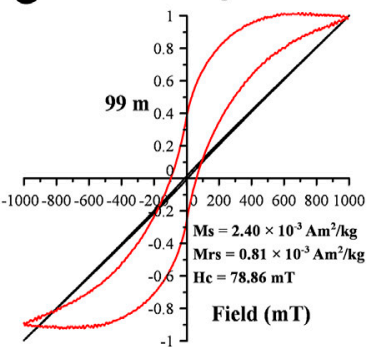

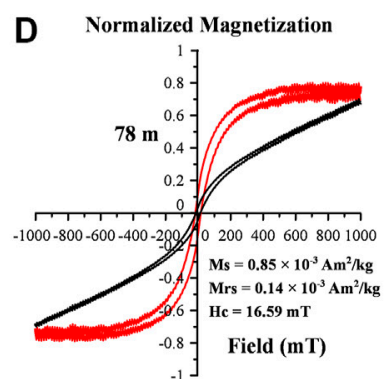

H Normalized Magnetization

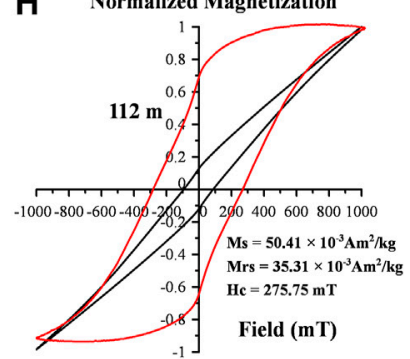

FIGURE 6|Representative hysteresis loops of the samples at various horizons of the Palpa section. The loops from samples with a low $\chi$ value are shown in (A-D) and a high $\chi$ value in (E-H). Note: Black and red lines indicate the curves before and after paramagnetism correction.

\section{Hysteresis Loops}

The hysteresis loops show that the intrinsic coercivities for all representative samples range from 5.51 to $193.76 \mathrm{mT}$. The very low Hc ranges from 5.5 to $10.6 \mathrm{mT}$, revealing ferromagnetic minerals as the major contributor. The hysteresis loops are either sigmoid-shaped slightly open to thin straight lines (closed type) at low fields (Figures 6A-C) and sometimes noisy (Figure 6D) but one with negative $\chi$ (at $65 \mathrm{~m}$ ), suggesting the predominance of low-coercivity ferromagnetic minerals (e.g., magnetite) masked by para- and/or diamagnetic contributions. However, the wasp-waisted (Figures 6E-G) and flat and wide shapes (Figure $\mathbf{6 H}$ ) indicate high coercivity, indicating a hard magnetic component (i.e., hematite). Generally, the wasp-waisted shapes are observed (Figures 6E-G) in samples with less than $10 \%$ of hematite or more than 50\% hematite (Da Silva et al., 2012). It is thus worth 


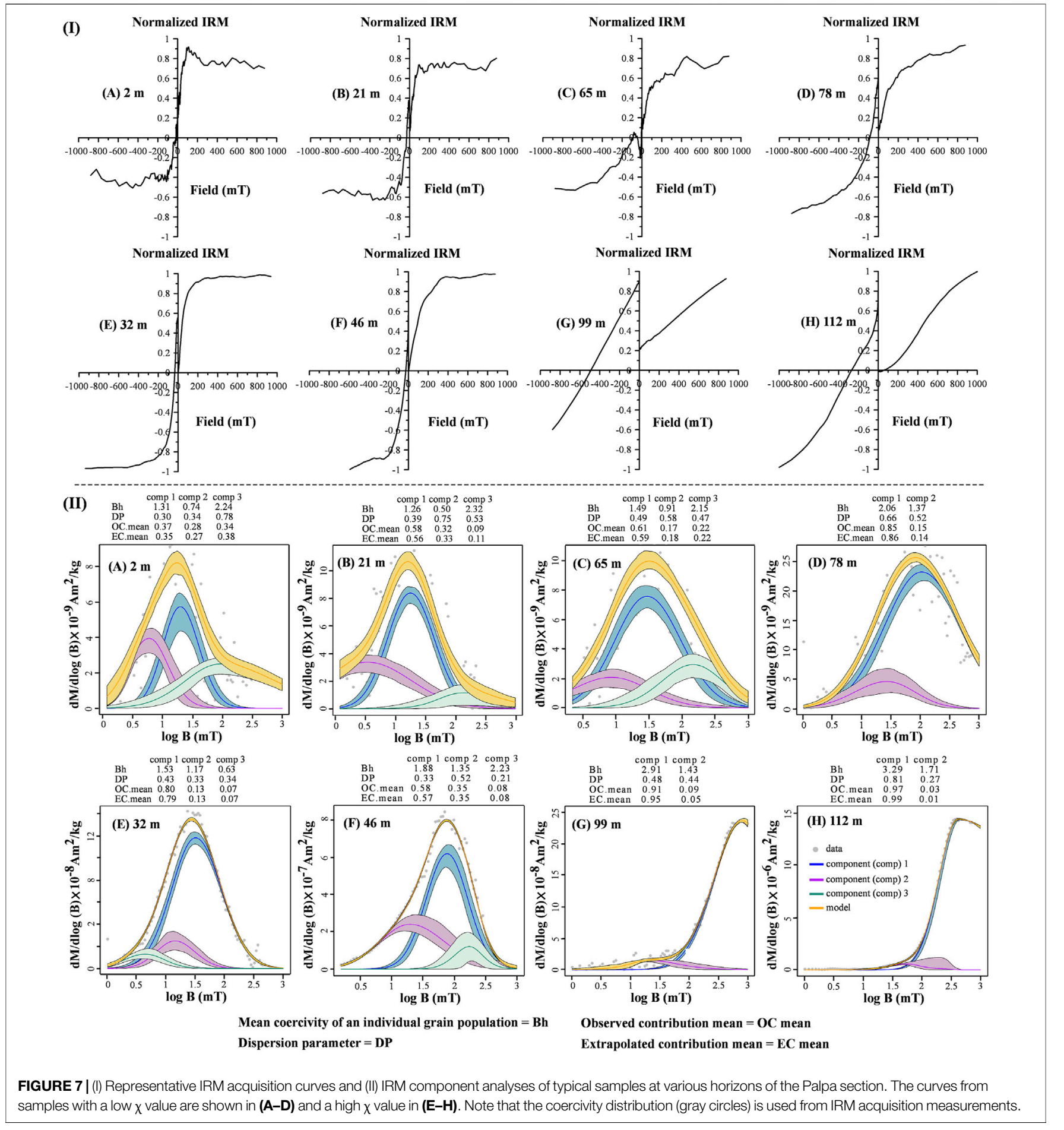

pointing out that these samples are typical for mixtures of lowand high-coercivity components and/or magnetic grain sizes (Roberts et al., 1995; Tauxe et al., 1996).

\section{Isothermal Remanent Magnetization}

Typical IRM acquisition curves (Figures 7A-C) show a sharp rise below $200 \mathrm{mT}$ and display weak magnetic intensities with very noisy intensities, representing the low-coercivity ferromagnetic minerals or soft magnetic minerals (e.g., magnetite and/or maghemite) as the major magnetic carrier. In contrast, the higher intensities of magnetization are represented by the gradual growth of IRM curves beyond $200 \mathrm{mT}$ and the fact that the curves do not saturate completely in a 1,000 $\mathrm{mT}$ field, signifying the occurrence of some hard magnetic minerals of high coercivity, most likely hematite, contributing to the remanence (Figures 7A,D-H). A slow increase in IRM can be observed after the applied magnetic field 
reaches $300 \mathrm{mT}$, indicating less hard magnetic minerals with a relatively high coercive force exist, which is consistent with the thermomagnetic curves of magnetic susceptibility (Figure 5).

Similarly, the methods for demagnetization curves or decomposing IRM acquisition provide insights into the low- and high-coercivity mineral assemblages (Heslop et al., 2002; Egli, 2004; Maxbauer et al., 2016). After decomposing the IRM acquisition data, the representative samples (Figure 7B) reveal three- and twocomponent model fits. The three distinct components were obtained from the IRM component analyses (Figures 7A-C,E,F) (Maxbauer et al., 2016). The parameter that shows the mean coercivity of an individual grain population from an assemblages of grains of a single magnetic grain is defined by the parameter $B_{h}$. Dispersion parameter (DP) is another parameter used as a measure of the variability of the physical and chemical processes that affect the grain microcoercivity. In order to calculate the relative contribution of each component to the total measured magnetization for each model component, the integrated area under individual component distributions are determined by the magnetic mineral contribution factor called as observed (OC) and extrapolated (EC) contribution (Egli, 2004; Maxbauer et al., 2016). The major contributor to the curves (Figures 7A-C) (component 1) have a mean coercivity of an individual grain population $\left(\mathrm{B}_{\mathrm{h}}\right)$ of $1.31,1.26$, and 1.49 , respectively, and a dispersion parameter (DP) of $0.30,0.69$ and 0.49 , respectively, indicating distinctive pedogenic or detrital soft components close to magnetite-like or phase. However, component 1 varies from 1.53 to 1.88 , and the DP has values of 0.33 and 0.42 (Figures 7B,E,F), typically indicating partially oxidized pedogenic magnetite (or hematite). Intermediate component 2 (Figures $\mathbf{7 A - C}$ ) is characterized by a $\mathrm{B}_{\mathrm{h}}$ of $0.5,0.74$, and 0.91 and a DP of $0.34,0.58$, and 0.74 , respectively, comparable to the partially oxidized pedogenic or detrital soft component, but $\mathrm{B}_{\mathrm{h}}$ varied from 1.17 to 1.35 and $\mathrm{DP}$ varies from 0.32 to 0.52 in Figures $7 \mathbf{B}, \mathbf{E}, \mathbf{F}$, which are typical of detrital soft components. The final component 3 (Figures $7 \mathrm{~A}-\mathrm{C}$ ) features a $\mathrm{B}_{\mathrm{h}}$ of $2.24,2.32$, and 2.15 and a DP of $0.78,0.53$, and 0.47 , respectively, indicating detrital soft components, but (Figures $7 \mathbf{B}, \mathbf{E}, \mathbf{F}$ ) has a $\mathrm{B}_{\mathrm{h}}$ of 0.62 and 2.23 and a DP of 0.21 and 0.34 , indicating partially oxidized pedogenic magnetite (or hematite). The decomposition of the IRM acquisition data reveals two primary magnetic components: component 1 , characterized by a $B_{h}$ of $2.06,2.91$, and 3.29 and a $\mathrm{DP}$ of $0.66,0.4$, and 0.81 , respectively, and component 2 , characterized by a $\mathrm{B}_{\mathrm{h}}$ of $1.37,1.43$, and 1.71 and a DP $0.52,0.44$ and 0.27 , respectively (Figures $\mathbf{7 B}, \mathbf{D}, \mathbf{G}, \mathbf{H}$ ). These components reveal finegrained hematite (component 1 ) and partially oxidized pedogenic magnetite (component 2) with either some detrital magnetite or a rare biogenic soft component (Egli, 2004; Lascu and Plank, 2013; Maxbauer et al., 2016).

\section{DISCUSSION}

\section{Magnetic Concentration-dependent Parameters From Different Magnetic Minerals in Relation to Tectonics}

The magnetic concentration-dependent parameters such as $\chi$, $\chi \mathrm{ARM}, \mathrm{SIRM}$, and HIRM are shown in Figure 3. In Figure 3, the low values of magnetic parameters in the terrestrial facies suggest low contents for the total magnetic mineral assemblage and antiferromagnetic components. These cases could be caused by the dissolution of fine-grained magnetite and the dissolution of antiferromagnetic minerals through microbial activities. The other possible driving factor could be the irregular deposition of sediments with low heavy mineral concentrations (Snowball and Thompson, 1990). In Figure 4C, the maximum Hc was observed in between $31-46 \mathrm{~m}$ and $99-113 \mathrm{~m}$ (marine facies). In addition, 2-29 $\mathrm{m}$ and 49-73 $\mathrm{m}$ (terrestrial facies) and also in 74-97 m (marine facies) display relatively lower Ms values, Hc, and Mrs/Ms ratios (Figures $4 \mathbf{A}, \mathbf{B}, \mathbf{D}$ ). When very strong linear relationships exist between Mrs and $\chi$, it suggests that the source of the magnetic minerals remains unaffected (Caitcheon, 1993; Eriksson and Sandgren, 1999; Meena et al., 2011). However, in Figures $\mathbf{8 A}, \mathbf{B}$, Mrs and $\chi$ show a very poor linear relation $\left(R^{2}=\right.$ 0.0006 ) for $31-46 \mathrm{~m}$ and $R^{2}=0.1321$ for $73-113 \mathrm{~m}$, inferring more possible sources for these existing magnetic inclusions (Figure 3) in the marine realm in the study area. In addition, a positive linear relationship $\left(R^{2}=0.8251\right.$ and 0.883$)$ exists between Ms and Mrs (Figures 8C,D) that denotes the magnetic concentration is controlled by magnetic mineralogy.

Figures 3, 4 show two distinct breaks in the curves respective to the significant change in the depositional setting (Figure 2), showing higher concentrations of primary magnetic grains with higher coercivity mineral assemblages, especially antiferromagnetic minerals or harder minerals, such as hematite. The presence of paramagnetic minerals (e.g., Fesilicates and Fe-oxyhydroxides) or weak magnetic oxides in the study area show low $\chi$ values (Figure 3A), probably associated with the allochthonous type and migrated through different fluvial channels or in situ environments. A gradual increase in $\chi \mathrm{fd} \%$ (Figure 3B) occurs in the siltstone, siliceous sandstone, and conglomerate beds of terrestrial facies, while the shale and siltstone beds bear less-weathered mineral grains resulting in higher $\chi$ and lower $\chi \mathrm{fd} \%$ spikes in the marine facies. In contrast, the marine facies exhibit higher SIRM, HIRM, and $\chi$ values but lower $\chi \mathrm{ARM}$ values than the terrestrial facies (Figure 3A,C-E). The greater values of these magnetic concentration-dependent parameters (Figure 3A,D,E) are probably induced by the drying phase of soil wetting/drying cycles through magnetite and $\mathrm{Fe}^{3+}$ oxide dissolution and/or drying by $\mathrm{Fe}^{3+}$ oxide during neoformed ultrafine magnetites (Fischer, 1988; Maher, 1998). Meanwhile, the $\chi$ ARM shows higher values (Figure 3C) formed by weak early diagenesis. Generally, the weak early diagenesis is affected by the local climatic environment during intense moist and sporadically reduced conditions, exhibiting wet and/or wet and warm conditions (Maher, 1998; Maher and Thompson, 1999; Maher et al., 2003). During this time, minor fluctuations in sea level have occurred (Müller et al., 2008), which in turn enhanced precipitation-induced erosional rate and deposits influx of magnetite- and hematite-bearing channel siltstone and shale (Figures 3G,H) into the existing basin or the continental shelf. Importantly, there was a constant collision-induced uplift of the Himalayan-Tibetan Plateau in this region. This leads to change in the sedimentary depositional environment (terrestrial and/or 

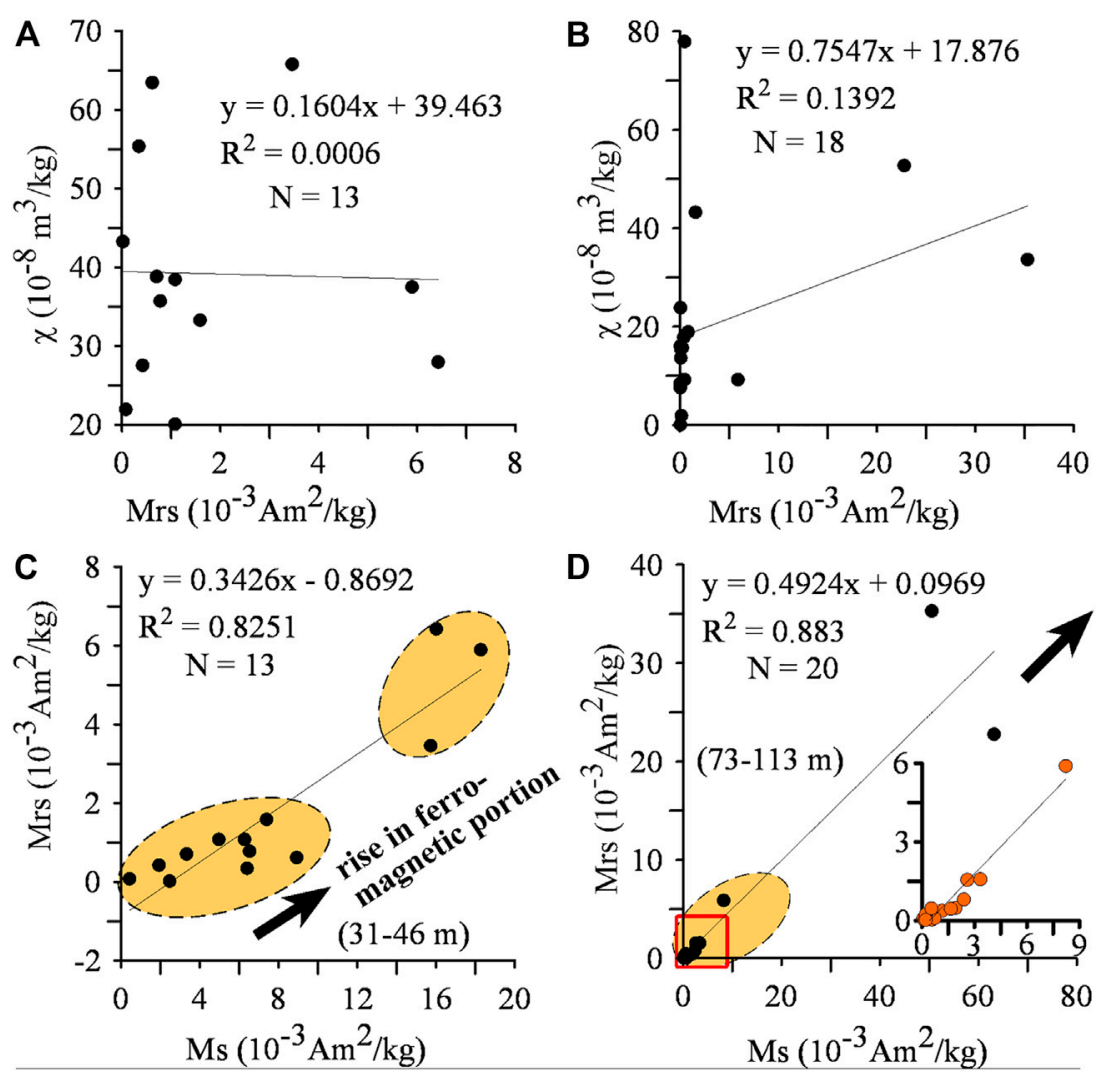

FIGURE 8 | (A-B) Bivariate plot of $\chi$ versus Mrs, a very low linear relation among both the concentration dependent. (C-D) Linear relation between Ms and Mrs display the magnetic mineral concentration for marine environment (31-46 $\mathrm{m}$ and $73-113 \mathrm{~m})$.

marine environments) with soft and hard magnetic minerals (Figures 8A,B) and provenance, which altered the channel inflows, continental weathering, erosion rate, and production of organic material within the depositional basin and modified the magnetic mineralogy to higher coercivity mineral assemblages (Figures 8C,D and Figure 9). The active tectonics highly influenced the concentrations of ferromagnetic minerals, such as magnetite, and hard minerals (e.g., hematite), which govern the magnetic signal within deposits forming in depositional environments that can be affected by changes in the regional climate (Figure 9).

\section{Prevailing Tectonic Control on the Depositional Basin}

The dynamic geomorphological features formed as a result of collision and uplift of the Himalaya, inducing cycles of transgression and regression, precipitation, and weathering causing rapid denudation. During the course of northward advancement of the Indian Plate, the basin plains might have had low areas with relatively constant deposition, in which changes in subsidence caused shifts between terrestrial and marine environments, adjusting the basin framework (e.g., the basins of Barahakshetra in the east, Tansen in the center, Tulsipur in the west and Birendranagar in the far west of Nepal). A simpler model can be postulated for the paleodepositional environment assessment of the late Cretaceous to middle Eocene strata (Figure 9). Zone I starts with a basal fluvial detritus in the form of siliceous sandstone followed by a pebbly conglomerate (Figures 2, 3), through local high-energy ephemeral channel systems derived from the adjacent highlands (not highlyelevated mountains), as a result of erosional processes, in response to active tectonics. These sediments are enriched in $\mathrm{Fe}$-silicates and $\mathrm{Fe}$-oxyhydroxides and some ferruginous nodules, probably showed earlier diagenetic processes under anoxic conditions (reducing conditions) developed by bacterial activities in the organic materials, and the high sulfate content possibly under brackish conditions, and occasionally under nonmarine conditions (Figure $\mathbf{2}$ and Figure 9A) (Harder, 1989; Yoshida et al., 1998; Shouyun et al., 2002). In addition, the multiple thin coal layers in zones I, II, and IIIA, with some ash and sulfur, sandwiched between greenish-gray sandstone and siltstone in zone I (Figure 2), originated from a peat swamp in a thick forest moor in a humid and marshy environment. These deposits probably formed within a reducing environment during the still-stand phase of marine transgression (Potter et al., 1980; Riegel, 1991; Sarkar and Prasad, 2000; Singh et al., 2010). Besides, the zones I, IIIA, and V consist of sandstones, conglomerates, and interbedded shales and sandstone which exhibit comparatively lower rock magnetic parameters values ( $\chi$, SIRM, and HIRM 
A

Active tectonics
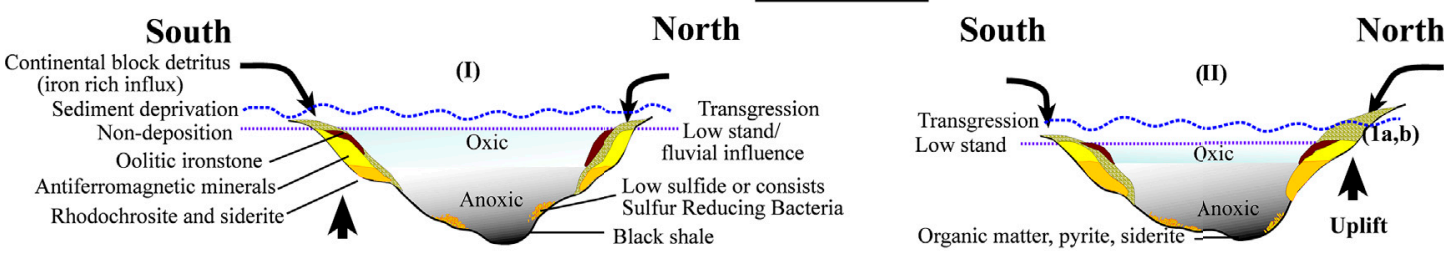

1. molasse deposit; a. relatively enriched hematite content when stable, b. both magnetite and hematite during tectonic uplift

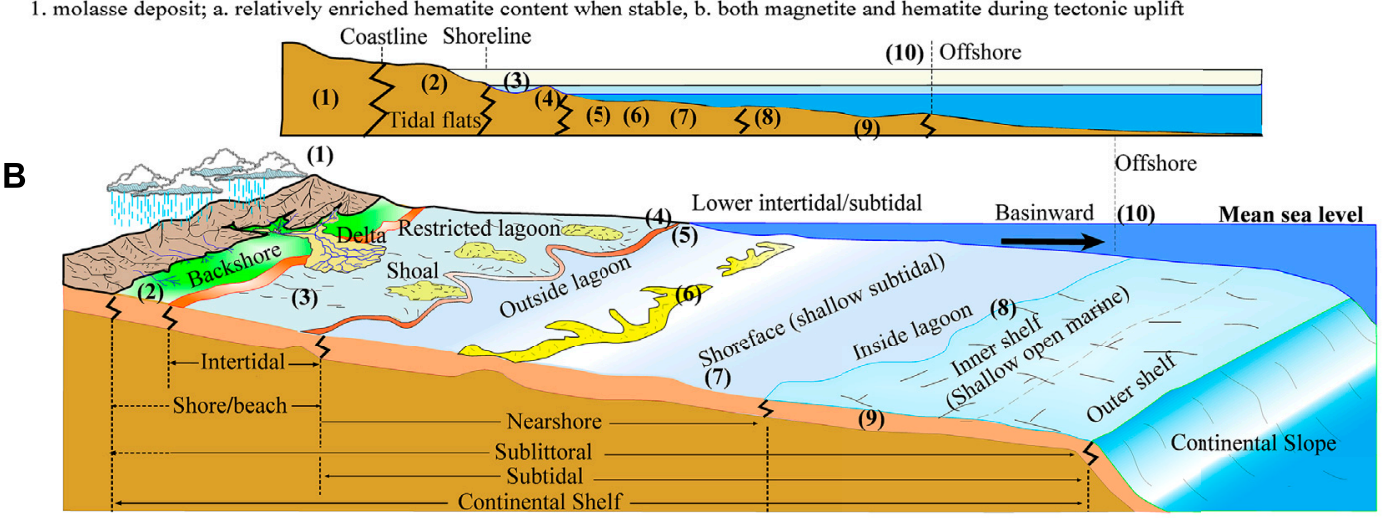

1. Paleo-uplift, 2. supratidal, 3. beach lagoon, 4. bioclastic bar, 5. marine margin, 6. oolitic shoal (barrier), 7. inner-ramp, 8. offshore transition 9. mid-ramp (deep subtidal, 10. fair weather wavebase

FIGURE 9 | (A) The plausible process for varied magnetic mineral composition in a depocenter in an active tectonic system: uplift slowly decreases in the southern part but increases rapidly in the northern part, in the Nepal Himalaya. (I) and (II) illustrates the depositional setting of how continental block detritus and magnetic minerals accumulate in a basin, in response to the tectonically active and inactive conditions. This type of depositional setting most likely controlled $\chi$ variation. (B) Schematic representation of the changes in the potential paleodepositional environments of the Amile and Bhainskati formations in the Lesser Himalaya, Nepal. It shows the probable accumulation of terrestrial and marine deposits (e.g., fine sediments or in the form of molasse deposits) during the marine transgression/regression process, with respect to the tectonic uplift during and after the Indian-Eurasian collision, ultimately affecting the magnetic enrichment within the basin.

values) (Figure 3), than zones II and IV and characterizes soft magnetic mineral assemblages. The repeated interbedding of carbonaceous sandstone and shale in zones I and IIIA (Figures 2, 3) by prograding low-energy fluvial systems can be linked with marginal marine influences, such as delta front environments (Figure 9B) (Mazumder et al., 2017). Meanwhile, the asymmetrical ripple marks in light gray siliceous sandstone (e.g., zone IIIA) also indicate deposition under fluvial conditions (Debenay and Guillou, 2002). These fluvial cycle changes after the transgression caused thick graygreen sandstone and occasional gray-red sandstone deposits in zone IIIA (Figures 2, 3).

Besides, the red-yellow weathering in the carbonaceous siltstone (e.g., zone II) and the gray-green silty shale followed by dark carbonaceous shale (e.g., from zone IIIB to IV) (Figure 2), formed due to higher organic production and relative oxygen-deficient bottom water caused by dysoxic or anoxic conditions, probably in a warm climate (Figure 9A) (Wignall, 1991; Lash and Blood, 2014). They show relatively high values of $\chi$, SIRM, and HIRM, though not $\chi \mathrm{ARM}$, and relatively low values of $\chi \mathrm{fd} \%$ (Figure 3 ). These high values are due to higher coercivity mineral assemblages such as the predominance of hematite over magnetite. The formation of a black shale to the upper part of green-red shale (e.g., zone IV) (Figure 2), indicates erosion from surrounding highlands and a eustatic sea level rise leading to marine invasion (Figure $\mathbf{3 H}$ ).
This condition usually occurs in calm water with low flow velocities associated with a weakened flooding phase (Allen, 1980; Sahni et al., 2004; Sisodia and Singh, 2000), and signifies the gradual regression of the Tethys Sea (Valdiya, 1980; Wells and Gingerich, 1987; Mathur, 1990; Srivastava and Kumar, 1996) (in Nepal, we termed it the Bhainskati Sea) with a hiatus in the deposition. This type of sedimentation in a euxinic environment might have been developed in a shallow sea with some tidal influence, such as in a protected lagoon with mud zones and tidal flats (Figure 9B) (Wallace-Dudley and Leckie, 1993; Willis et al., 1999; Bhatia and Bhargava, 2006; Singh et al., 2010; Krim et al., 2017). The fine sediments (e.g., zone II) are thought to have been derived from the Indian cratonic succession and the remobilization of previously deposited arenaceous sequences (Garzanti, 1999), originally by a northward-flowing drainage system in the late Cretaceous time (Gansser, 1964; Sakai, 1983; DeCelles et al., 1998; DeCelles et al., 2004; DeCelles et al., 2014). However, the sediments of zone IIIB and IV include mixed recycled Indian craton concealed basement rocks (probably from the northeastern volcanic rocks of India) and the Himalayan units (probably the Tethyan sedimentary rock sequences) (DeCelles et al., 2004; Gehrels et al., 2011). The iron ore deposits in high-grade metasedimentary and lowgrade volcano-sedimentary rocks in the Singhbhum and Bundelkhand Cratons of greenstone belt successions (from the Indian subcontinent) (Saha, 1994; Mukhopadhyay et al., 2008; 
Chattopadhyay et al., 2015; Mukhopadhyay, 2020) might have been transported to the Amile and Bhainskati formations. Also, the metasediments from the Bastar Craton (Dora et al., 2020) and other metamorphosed rocks from the Aravalli Craton (Crawford, 1970) are thought to be present occasionally in the late Cretaceous to middle Eocene strata.

It is interesting to point out that the relative rise in sea level drowned the southern highlands, and a shallow marine environment developed briefly in the late Cretaceous strata and ceased with a progressive shift to continental sedimentation. Some larger foraminifera, oysters, sharks, pelecypods (bivalves), gastropods, echinoids, screleactinean corals, and vertebrate fossils are reported from the argillaceous limestone of the Amile Formation (middle part) (e.g., zone II) (Sakai, 1983), acted as barriers (Figure 9B) (Wright and Burchette, 1996). Furthermore, the larger foraminifers (Sakai, 1983; Matsumaru and Sakai, 1989), bivalves, gastropods, Teleostei, Asteracantus sp., Chelonia and Trionichidae carapaces (Sakai, 1983), and pristichampsinae (Sah and Schleich, 1990) in the Bhainskati Formation (e.g., zone IV) have been interpreted as indications of an aquatic environment, allowing productive shallow sea level conditions (Reineck and Singh, 1980). As the reflooding caused the deposition of basal intraformational conglomerate (mudpebble conglomerate) beds (e.g., zone v) (Dumri Formation) (Figure 2) eroded from the northern uplifted mountain ranges during the late Oligocene to early Miocene. It represents the final regression uplift caused by the tectonic stress in the Himalayan belt. The cessation of deposition could correspond to the timing of the India-Asia collision and the disappearance of the Bhainskati seaway in the Nepal region as a result of Himalayan uplift. Furthermore, the lack of mud cracks in the study area indicates that the basin was not completely in the shallowing stage and that exposure of the sediments did not occur under totally dry conditions. We also argue that the local geomorphology played a significant role in the development of magnetic mineralogy in this section and that the nature of sediment influx (of either autochthonous or allochthonous origin) was influenced by local drainage patterns and seawater conditions in the depositional basin, with enhancement by active tectonics.

\section{CONCLUSION}

The results suggest the complex mechanisms operating during the collision between the Indian and Eurasian plates and the early stages of uplift of the Himalayan orogen. Firstly, the major change inferred from abrupt breaks in the $\chi$, SIRM and HIRM, and lithological differences, which are concluded to have developed due to the modification of the depositional environment during the deposition of the late Cretaceous to middle Eocene strata.
Secondly, the active tectonics influenced SIRM, HIRM, and hysteresis loops with the concentrations of ferromagnetic minerals, such as magnetite, and hard minerals (e.g., hematite) formed in the terrestrial (zones I, IIIA, and V) and marine (zones II, IIIB and IV) facies respectively. We suggest that the forementioned rock magnetic changes from the sediments during the late Cretaceous to middle Eocene had been affected by the alternating warm-dry and warm-humid regional climate associated with the regression and transgression of the Tethys Sea as a result of the Indian-Eurasian collision.

\section{DATA AVAILABILITY STATEMENT}

The datasets presented in this study can be found in online repositories. The names of the repository/repositories and accession number(s) can be found below: http://figshare.com/s/ 6de59e47d56dd81aca78.

\section{AUTHOR CONTRIBUTIONS}

DK: Conceptualization, Methodology, Formal analysis, Writing-Review and Editing, Investigation. WZ: Conceptualization, Formal analysis, Investigation, Resources, Supervision. XF: Investigation, Resources, Supervision. QM: Investigation. TZ: Investigation. DZ: Investigation. KP: Investigation.

\section{FUNDING}

This work is co-supported by the Second Tibetan Plateau Scientific Expedition and Research (Grant 2019QZKK0707), the Strategic Priority Research Program of the Chinese Academy of Sciences (Grant XDA20070201), the National Basic Research Program of China (Grant 2017YFC0602803), the Basic Science Center for Tibetan Plateau Earth System (CTPES, Grant 41988101-01), the External Cooperation Program (Grant 131C11KYSB20160072) and also partly supported by CAS-TWAS president's fellowship program (2019).

\section{ACKNOWLEDGMENTS}

We thank Dr. Wu Fuli, Xie Yulong, and Guo Haichao for their field assistance, and Prof. Dr. Lalu Prasad Paudel (former head of department from Central Department of Geology, Tribhuvan University, Kirtipur) and Dr. Somnath Sapkota (Department of Mining and Geology, Lainchaur, Kathmandu, Nepal) for providing administrative help during our fieldwork. We also appreciate Prof. Dr. Zan Jinbo for his constructive discussions and suggestions. 


\section{REFERENCES}

Allen, J. R. L. (1980). Sand Waves: A Model of Origin and Internal Structure. Sediment. Geol. 26, 281-328. doi:10.1016/0037-0738(80)90022-6

Ao, H., Deng, C., Dekkers, M. J., and Liu, Q. (2010). Magnetic Mineral Dissolution in Pleistocene Fluvio-Lacustrine Sediments, Nihewan Basin (North China). Earth Planet. Sci. Lett. 292, 191-200. doi:10.1016/j.epsl.2010.01.035

Appel, E., Müller, R., and Widder, R. W. (1991). Palaeomagnetic Results from the Tibetan Sedimentary Series of the Manang Area (North central Nepal). Geophys. J. Int. 104, 255-266. doi:10.1111/j.1365-246x.1991.tb02510.x

Beck, R. A., Burbank, D. W., Sercombe, W. J., Riley, G. W., Barndt, J. K., Berry, J. R., et al. (1995). Stratigraphic Evidence for an Early Collision between Northwest India and Asia. Nature 373, 55-58. doi:10.1038/373055a0

Bhandari, S., Xiao, W., Ao, S., Windley, B. F., Li, R., and Esmaeili, R. (2019). Detrital Geochronology of the Gondwana Sequence of the Lesser Himalaya of the Nepal Himalaya. Geol. J. 54, 3909-3920. doi:10.1002/gj.3365

Bhatia, S. B., and Bhargava, O. N. (2006). Biochronological Continuity of the Paleogene Sediments of the Himalayan Foreland Basin: Paleontological and Other Evidences. J. Asian Earth Sci. 26, 477-487. doi:10.1016/j.jseaes.2004.10.007

Boos, W. R., and Kuang, Z. (2010). Dominant Control of the South Asian Monsoon by Orographic Insulation Versus Plateau Heating. Nature 463, 218-222. doi:10.1038/nature08707

Bosboom, R. E., Dupont-Nivet, G., Houben, A. J. P., Brinkhuis, H., Villa, G., Mandic, O., et al. (2011). Late Eocene Sea Retreat from the Tarim Basin (West China) and Concomitant Asian Paleoenvironmental Change. Palaeogeogr. Palaeoclimatol. Palaeoecol. 299, 385-398. doi:10.1016/j.palaeo.2010.11.019

Bosboom, R. E., Abels, H. A., Hoorn, C., Van Den Berg, B. C. J., Guo, Z., and Dupont-Nivet, G. (2014). Aridification in continental Asia after the Middle Eocene Climatic Optimum (MECO). Earth Planet. Sci. Lett. 389, 34-42. doi:10.1016/j.epsl.2013.12.014

Caitcheon, G. G. (1993). Sediment Source Tracing Using Environmental Magnetism: A New Approach with Examples from Australia. Hydrol. Process. 7, 349-358. doi:10.1002/hyp.3360070402

Chattopadhyay, S., Upadhyay, D., Nanda, J. K., Mezger, K., Pruseth, K. L., and Berndt, J. (2015). Proto-India Was a Part of Rodinia: Evidence from Grenville-Age Suturing of the Eastern Ghats Province with the Paleoarchean Singhbhum Craton. Precambrian Res. 266, 506-529. doi:10.1016/j.precamres.2015.05.030

Crawford, A. R. (1970). The Precambrian Geochronology of Rajasthan and Bundelkhand, Northern India. Can. J. Earth Sci. 7, 91-110. doi:10.1139/e70-007

Crouzet, C., Stang, H., Appel, E., Schill, E., and Gautam, P. (2001). Detailed Analysis of Successive pTRMs Carried by Pyrrhotite in Himalayan Metacarbonates: an Example from Hidden Valley, Central Nepal. Geophys. J. Int. 146, 607-618. doi:10.1046/j.0956-540x.2001.01478.x

Da Silva, A.-C., Dekkers, M. J., Mabille, C., and Boulvain, F. (2012). Magnetic Susceptibility and its Relationship with Paleoenvironments, Diagenesis and Remagnetization: Examples from the Devonian Carbonates of Belgium. Stud. Geophys. Geod. 56, 677-704. doi:10.1007/s11200-011-9005-9

Debenay, J.-P., and Guillou, J.-J. (2002). Ecological Transitions Indicated by Foraminiferal Assemblages in Paralic Environments. Estuaries 25, 1107-1120. doi:10.1007/BF02692208

DeCelles, P. G., Gehrels, G. E., Quade, J., and Ojha, T. P. (1998). Eocene-early Miocene Foreland basin Development and the History of Himalayan Thrusting, Western and central Nepal. Tectonics 17, 741-765. doi:10.1029/98TC02598

DeCelles, P. G., Cehrels, G. E., Quade, J., Lareau, B., and Spurlin, M. (2000). Tectonic Implications of U-Pb Zircon Ages of the Himalayan Orogenic Belt in Nepal. Science 288, 497-499. doi:10.1126/science.288.5465.497

DeCelles, P. G., Gehrels, G. E., Najman, Y., Martin, A. J., Carter, A., and Garzanti, E. (2004). Detrital Geochronology and Geochemistry of Cretaceous-Early Miocene Strata of Nepal: Implications for Timing and Diachroneity of Initial Himalayan Orogenesis. Earth Planet. Sci. Lett. 227, 313-330. doi:10.1016/j.epsl.2004.08.019

DeCelles, P. G., Kapp, P., Gehrels, G. E., and Ding, L. (2014). Paleocene-Eocene Foreland basin Evolution in the Himalaya of Southern Tibet and Nepal: Implications for the Age of Initial India-Asia Collision. Tectonics 33, 824-849. doi:10.1002/2014TC003522

Dhital, M. R. (2015). Geology of the Nepal Himalaya: Regional Perspective of the Classic Collided Orogen. Switzerland: Springer. doi:10.1007/978-3-319-02496-7
Dora, M. L., Upadhyay, D., Randive, K. R., Shareef, M., Baswani, S. R., and Ranjan, S. (2020). Trace Element Geochemistry of Magnetite and Pyrite and Sulfur Isotope Geochemistry of Pyrite and Barite from the Thanewasna $\mathrm{Cu}-(\mathrm{Au})$ deposit, Western Bastar Craton, central India: Implication for Ore Genesis. Ore Geol. Rev. 117, 103262. doi:10.1016/j.oregeorev.2019.103262

Egli, R. (2004). Characterization of Individual Rock Magnetic Components by Analysis of Remanence Curves, 1. Unmixing Natural Sediments. Studia Geophys. Geod. 48, 391-446. doi:10.1023/B:SGEG.0000020839.45304.6d

Eriksson, M. G., and Sandgren, P. (1999). Mineral Magnetic Analyses of Sediment Cores Recording Recent Soil Erosion History in central Tanzania. Palaeogeogr. Palaeoclimatol. Palaeoecol. 152, 365-383. doi:10.1016/S0031-0182(99)00043-7

Fischer, W. R. (1988). "Microbiological Reactions of Iron in Soils," in Iron in Soils and clay Minerals (Dordrecht, Holland: Springer), 715-748. doi:10.1007/97894-009-4007-9_20

Gansser, A. (1964). Geology of the Himalayas. New York: Interscience, 289.

Garzanti, E., and Frette, M. P. (1991). Stratigraphic Succession of the Thakkhola Region (Central Nepal)-Comparison with the Northwestern Tethys Himalaya. Rivista Ital. di Paleontol. e Stratigr. (Res. Paleontol. Stratigr.) 97, 3-26. doi:10.13130/2039/2039-4942/8980

Garzanti, E. (1999). Stratigraphy and Sedimentary History of the Nepal Tethys Himalaya Passive Margin. J. Asian Earth Sci. 17, 805-827. doi:10.1016/S13679120(99)00017-6

Gautam, P., and Appel, E. (1994). Magnetic-polarity Stratigraphy of Siwalik Group Sediments of Tinau Khola Section in West central Nepal, Revisited. Geophys. J. Int. 117, 223-234. doi:10.1111/j.1365-246X.1994.tb03314.x

Gautam, P., and Fujiwara, Y. (2000). Magnetic Polarity Stratigraphy of Siwalik Group Sediments of Karnali River Section in Western Nepal. Geophys. J. Int. 142, 812-824. doi:10.1046/j.1365-246x.2000.00185.x

Gautam, P., and Pant, S. R. (1996). Magnetic Fabric of Siwalik Group Sediments of Tinau Khola Section, West central Nepal. Bull. Dept. Geol. 5, 21-36.

Gautam, P., Upreti, B., and Arita, K. (1995). Paleomagnetism and Petrochemistry of the Dowar Khola Volcanics, central Nepal Sub Himalaya. J. Nepal Geol. Soc. 11, 179-195. doi:10.3126/jngs.v11i0.32792

Gautam, P., Ulak, P., Gyawali, B., and Bhandari, S. (2011). Magnetic Susceptibility of Some Lesser Himalayan Rocks in central Nepal. J. Nepal Geol. Soc. 43, 31-40. doi:10.3126/jngs.v43i0.25144

Gautam, P. (1989a). Magnetic Properties of Some Late Paleozoic to Tertiary Sedimentary Rocks of Tansen Area, Lesser Himalaya, Nepal. J. Fac. Sci. Hokkaido Univ. Ser, 1v 22, 467-487.

Gautam, P. (1989b). Multi-Component Remanent Magnetization in the Aulis Volcanics, the Lesser Himalaya, Nepal. J. Geomagn. Geoelec 41, 101-117. doi:10.5636/jgg.41.101

Gautam, P. (2008). Magnetic Fabric of Siwalik Sediments (Nepal): Implications to Time-Space Evolution of Stress Field. J. Nepal Geol. Soc. 38, 39-48. doi:10.3126/ jngs.v38i0.31480

Gehrels, G., Kapp, P., Decelles, P., Pullen, A., Blakey, R., Weislogel, A., et al. (2011). Detrital Zircon Geochronology of Pre-Tertiary Strata in the Tibetan-Himalayan Orogen. Tectonics 30, TC5016. doi:10.1029/2011TC002868

Ghosh, P., Bhattacharya, S. K., and Jani, R. A. (1995). Palaeoclimate and Palaeovegetation in central India during the Upper Cretaceous Based on Stable Isotope Composition of the Palaeosol Carbonates. Palaeogeogr. Palaeoclimatol. Palaeoecol. 114, 285-296. doi:10.1016/0031-0182(94)00082-J

Guillot, S., Mahéo, G., De Sigoyer, J., Hattori, K. H., and Pêcher, A. (2008). Tethyan and Indian Subduction Viewed from the Himalayan High- to Ultrahigh-Pressure Metamorphic Rocks. Tectonophysics 451, 225-241. doi:10.1016/j.tecto.2007.11.059

Harder, H. (1989). Mineral Genesis in Ironstones: a Model Based upon Laboratory Experiments and Petrographic Observations. Geol. Soc. Lond. Spec. Publ. 46, 9-18. doi:10.1144/GSL.SP.1989.046.01.04

Heslop, D., Dekkers, M. J., Kruiver, P. P., and Van Oorschot, I. H. M. (2002). Analysis of Isothermal Remanent Magnetization Acquisition Curves Using the Expectation-Maximization Algorithm. Geophys. J. Int. 148, 58-64. doi:10.1046/ j.0956-540x.2001.01558.x

Ji, J., Shen, J., Balsam, W., Chen, J., Liu, L., and Liu, X. (2005). Asian Monsoon Oscillations in the Northeastern Qinghai-Tibet Plateau since the Late Glacial as Interpreted from Visible Reflectance of Qinghai Lake Sediments. Earth Planet. Sci. Lett. 233, 61-70. doi:10.1016/j.epsl.2005.02.025

Khatri, D., Zhang, W., Fang, X., and Paudayal, K. N. (2017). Review of Late Cenozoic Climatic Fingerprints in the Nepal Himalaya. Bull. Nepal Geol. Soc. 34, 87-96. 
Kimura, T., Bose, M., and Sakai, H. (1985). Fossil Plant Remains from Taltung Formation, Palpa District, Nepal Lesser Himalaya. Bull. Natl. Sci. Mus. Ser. C $11,141-153$.

Krim, N., Bonnel, C., Tribovillard, N., Imbert, P., Aubourg, C., Riboulleau, A., et al. (2017). Paleoenvironmental Evolution of the Southern Neuquèn basin (Argentina) during the Tithonian-Berriasian (Vaca Muerta and Picún Leufú Formations): A Multi-Proxy Approach. Bull. Soc. Géol. Fr. 188, 34. doi:10.1051/bsgf/2017196

Kruiver, P. P., Langereis, C. G., Dekkers, M. J., and Krijgsman, W. (2003). Rockmagnetic Properties of Multicomponent Natural Remanent Magnetization in Alluvial Red Beds (NE Spain). Geophys. J. Int. 153, 317-332. doi:10.1046/j.1365246X.2003.01880.x

Lascu, I., and Plank, C. (2013). A New Dimension to Sediment Magnetism: Charting the Spatial Variability of Magnetic Properties across lake Basins. Glob. Planet. Change 110, 340-349. doi:10.1016/j.gloplacha.2013.03.013

Lash, G. G., and Blood, D. R. (2014). Organic Matter Accumulation, Redox, and Diagenetic History of the Marcellus Formation, Southwestern Pennsylvania, Appalachian basin. Mar. Pet. Geol. 57, 244-263. doi:10.1016/j.marpetgeo.2014.06.001

Licht, A., France-Lanord, C., Reisberg, L., Fontaine, C., Soe, A. N., and Jaeger, J.-J. (2013). A Palaeo Tibet-Myanmar Connection? Reconstructing the Late Eocene Drainage System of central Myanmar Using a Multi-Proxy Approach. J. Geol. Soc. 170, 929-939. doi:10.1144/jgs2012-126

Licht, A., Van Cappelle, M., Abels, H. A., Ladant, J.-B., Trabucho-Alexandre, J., France-Lanord, C., et al. (2014). Asian Monsoons in a Late Eocene Greenhouse World. Nature 513, 501-506. doi:10.1038/nature13704

Liu, Q., Roberts, A. P., Larrasoaña, J. C., Banerjee, S. K., Guyodo, Y., Tauxe, L., et al. (2012). Environmental Magnetism: Principles and Applications. Rev. Geophys. 50, RG4002. doi:10.1029/2012RG000393

Maher, B. A., and Thompson, R. (1999). Palaeomonsoons I: The Magnetic Record of Palaeoclimate in the Terrestrial Loess and Palaeosol Sequences. Quat. Clim. Environ. Magn. 81-125. doi:10.1017/cbo9780511535635.004

Maher, B. A., Alekseev, A., and Alekseeva, T. (2003). Magnetic Mineralogy of Soils across the Russian Steppe: Climatic Dependence of Pedogenic Magnetite Formation. Palaeogeogr. Palaeoclimatol. Palaeoecol. 201, 321-341. doi:10.1016/S0031-0182(03)00618-7

Maher, B. A. (1998). Magnetic Properties of Modern Soils and Quaternary Loessic Paleosols: Paleoclimatic Implications. Palaeogeogr. Palaeoclimatol. Palaeoecol. 137, 25-54. doi:10.1016/S0031-0182(97)00103-X

Martin, A. J., Burgy, K. D., Kaufman, A. J., and Gehrels, G. E. (2011). Stratigraphic and Tectonic Implications of Field and Isotopic Constraints on Depositional Ages of Proterozoic Lesser Himalayan Rocks in central Nepal. Precambrian Res. 185, 1-17. doi:10.1016/j.precamres.2010.11.003

Martin, A. J. (2017). A Review of Definitions of the Himalayan Main Central Thrust. Int. J. Earth Sci. (Geol Rundsch) 106, 2131-2145. doi:10.1007/s00531-016-1419-8

Mathur, N. S. (1990). Tethyan Cretaceous Sediments in the Northwest Himalaya. Cretaceous Res. 11, 289-305. doi:10.1016/S0195-6671(05)80013-8

Matsumaru, K., and Sakai, H. (1989). "Nummulites and Assilina from Tansen Area, Palpa District, The Nepal Lesser Himalayas," in Transactions and Proceedings of the Paleontological Soc. Japan (New Ser: Palaeontological Society of Japan), 68-76. doi:10.14825/prpsj1951.1989.154_68

Maxbauer, D. P., Feinberg, J. M., and Fox, D. L. (2016). Magnetic mineral Assemblages in Soils and Paleosols as the Basis for Paleoprecipitation Proxies: A Review of Magnetic Methods and Challenges. Earth-Sci. Rev. 155, 28-48. doi:10.1016/j.earscirev.2016.01.014

Mazumder, S., Tep, B., Pangtey, K. K. S., Das, K. K., and Mitra, D. S. (2017). Probable Existence of a Gondwana Transcontinental Rift System in Western India: Implications in Hydrocarbon Exploration in Kutch and Saurashtra Offshore: A GIS-Based Approach. J. Earth Syst. Sci. 126, 81. doi:10.1007/s12040-017-0866-3

Meena, N. K., Maiti, S., and Shrivastava, A. (2011). Discrimination between Anthropogenic (Pollution) and Lithogenic Magnetic Fraction in Urban Soils (Delhi, India) Using Environmental Magnetism. J. Appl. Geophys. 73, 121-129. doi:10.1016/j.jappgeo.2010.12.003

Mehrotra, R. C. (2003). Status of Plant Megafossils during the Early Paleogene in India. Geol. Soc. Am. Sp. Pap. 369, 413-423. doi:10.1130/0-8137-2369-8.413

Mohabey, D. M., Udhoji, S. G., and Verma, K. K. (1993). Palaeontological and Sedimentological Observations on Nonmarine Lameta Formation (Upper Cretaceous) of Maharashtra, India: Their Palaeoecological and Palaeoenvironmental Significance. Palaeogeogr. Palaeoclimatol. Palaeoecol. 105, 83-94. doi:10.1016/0031-0182(93)90108-U
Molnar, P., and Tapponnier, P. (1975). Cenozoic Tectonics of Asia: Effects of a Continental Collision: Features of Recent continental Tectonics in Asia Can Be Interpreted as Results of the India-Eurasia Collision. Science 189, 419-426. doi:10.1126/science.189.4201.419

Müller, R. D., Sdrolias, M., Gaina, C., Steinberger, B., and Heine, C. (2008). Longterm Sea-Level Fluctuations Driven by Ocean basin Dynamics. Science 319, 1357-1362. doi:10.1126/science.1151540

Mukhopadhyay, J., Beukes, N. J., Armstrong, R. A., Zimmermann, U., Ghosh, G., and Medda, R. A. (2008). Dating the Oldest Greenstone in India: a 3.51-Ga Precise U-Pb SHRIMP Zircon Age for Dacitic Lava of the Southern Iron Ore Group, Singhbhum Craton. J. Geol. 116, 449-461. doi:10.1086/590133

Mukhopadhyay, J. (2020). Archean Banded Iron Formations of India. Earth-Sci. Rev. 201, 102927. doi:10.1016/j.earscirev.2019.102927

Murdock, K. J., Wilkie, K., and Brown, L. L. (2013). Rock Magnetic Properties, Magnetic Susceptibility, and Organic Geochemistry Comparison in Core LZ1029-7 Lake El'gygytgyn, Russia Far East. Clim. Past 9, 467-479. doi:10.5194/cp-9-467-2013

Najman, Y., Carter, A., Oliver, G., and Garzanti, E. (2005). Provenance of Eocene Foreland basin Sediments, Nepal: Constraints to the Timing and Diachroneity of Early Himalayan Orogenesis. Geol 33, 309-312. doi:10.1130/G21161.1

Najman, Y., Jenks, D., Godin, L., Boudagher-Fadel, M., Millar, I., Garzanti, E., et al. (2017). The Tethyan Himalayan Detrital Record Shows that India-Asia Terminal Collision Occurred by $54 \mathrm{Ma}$ in the Western Himalaya. Earth Planet. Sci. Lett. 459, 301-310. doi:10.1016/j.epsl.2016.11.036

Neupane, B., and Zhao, J. (2018). Detrital Zircon U-Pb Age and Petrographic Composition from Foreland Sediments of the Tansen Basin, Central Nepal: Constraints on Sediment Provenance and Tectonics of the central Himalaya. Archaeol. Anthropol. 3, 56-69. doi:10.31031/AAOA.2018.03.000558

Neupane, B., Ju, Y., Allen, C. M., Ulak, P. D., and Han, K. (2017). Petrography and Provenance of Upper Cretaceous - Palaeogene Sandstones in the Foreland basin System of Central Nepal. Int. Geol. Rev. 60, 135-156. doi:10.1080/ 00206814.2017.1312716

Neupane, B., Zhao, J., Gyawali, B. R., Deng, Y., Maharjan, B., and Nepal, R. (2021). Depositional Environment of Upper Paleocene - Middle Eocene Series of the Lesser Himalaya, Central Nepal. Lithos 388-389, 106060. doi:10.1016/ j.lithos.2021.106060

Ojha, T. P., Butler, R. F., Decelles, P. G., and Quade, J. (2009). Magnetic Polarity Stratigraphy of the Neogene Foreland basin Deposits of Nepal. Basin Res. 21, 61-90. doi:10.1111/j.1365-2117.2008.00374.x

Pant, S. R., Gautam, P., Dhital, M. R., and Sharma, M. P. (1992). On the Remanent Magnetization of Some Rocks from Dang Lesser Himalaya, Nepal. Bull. Dept. Geol. 2, 57-63.

Parrish, R. R., and Hodges, V. (1996). Isotopic Constraints on the Age and Provenance of the Lesser and Greater Himalayan Sequences, Nepalese Himalaya. Geol. Soc. Am. Bull. 108, 904-911. doi:10.1130/0016-7606(1996) 108<0904:ICOTAA >2.3.CO;2

Potter, P. E., Maynard, J. B. A., and Pryor, A. W. (1980). Sedimentology of Shale. New York: Springer-Verlag, 310.

Prasad, V., Farooqui, A., Murthy, S., Sarate, O. S., and Bajpai, S. (2018). Palynological Assemblage from the Deccan Volcanic Province, central India: Insights into Early History of Angiosperms and the Terminal Cretaceous Paleogeography of Peninsular India. Cretaceous Res. 86, 186-198. doi:10.1016/j.cretres.2018.03.004

Reineck, H.-E., and Singh, I. B. (1980). "Lake Environment," in Depositional Sedimentary Environments (Berlin, Heidelberg: Springer), 241-256. doi:10.1007/ 978-3-642-81498-3_18

Riegel, W. (1991). "Coal Cyclothems and Some Models for Their Origin," in Cycles and Events in Stratigraphy (Verlag Berlin: Springer), 733-750.

Roberts, A. P., Cui, Y., and Verosub, K. L. (1995). Wasp-waisted Hysteresis Loops: Mineral Magnetic Characteristics and Discrimination of Components in Mixed Magnetic Systems. J. Geophys. Res. 100, 17909-17924. doi:10.1029/95JB00672

Robinson, D. M., Decelles, P. G., Patchett, P. J., and Garzione, C. N. (2001). The Kinematic Evolution of the Nepalese Himalaya Interpreted from Nd Isotopes. Earth Planet. Sci. Lett. 192, 507-521. doi:10.1016/S0012-821X(01)00451-4

Sah, R. B., and Schleich, H. H. (1990). An Eocene Crocodile Record from Bhainskati Khola. Mitt. Bayer. Staatsslg. Paläont. Hist. Geo. München 30, 51-56.

Saha, A. K. (1994). Crustal Evolution of Singhbhum North Orissa Eastern India. Mem. Geol. Soc India 59 (397), 773. doi:10.1180/minmag.1995.059.397.25 
Sahni, A., Rana, R., Loyal, R., Saraswati, P., Mathur, S., Rose, K., Tripathi, S., and Garg, R. (2004). "Western Margin Palaeocene-Lower Eocene Lignites: Biostratigraphic and Palaeoecological Constraints," in Proceedings of 2nd APG Conference cum Exhibition, Khajuraho, 1-22.

Sakai, H. (1983). Geology of the Tansen Group of the Lesser Himalaya in Nepal. Mem. Fac. Sci. Kyushu Univ. 25, 27-74. doi:10.5109/1546083

Sakai, H. (1984). Stratigraphy of Tansen Area in the Nepal Lesser Himalayas. J. Nepal Geol. Soc. 4, 41-52.

Sakai, H. (1985). Geology of the Kali Gandaki Supergroup of the Lesser Himalayas in Nepal. Mem. Fac. Sci. Kyushu Univ. Ser. D, Geol. 25, 337-397. doi:10.5109/1546320

Sakai, H. (1989). "Rifting of the Gondwanaland and Uplifting of the Himalayas Recorded in Mesozoic and Tertiary Fluvial Sediments in the Nepal Himalayas," in Sedimentary Facies in the Active Plate Margin (Tokyo: Terra Scientific Publishing Company), 723-732.

Samant, B., Kapgate, D. K., Kumar, D., Mohabey, D. M., and Dhoble, A. (2020). Maastrichtian Palynoflora from Deccan Volcanic Associated Sediments of Mahurzari, Nagpur District, Maharashtra: Age and Paleoenvironment with Comments on Megaflora. J. Geol. Soc. India 95, 475-482. doi:10.1007/s12594020-1464-6

Sarkar, S., and Prasad, V. (2000). Palynostratigraphy and Depositional Environment of the Subathu Formation (Late Ypresian-Middle Lutetian), Morni Hills, Haryana, India. J. Palaeontol. Soc. India 45, 137-149.

Scheinost, A. C., Chavernas, A., Barrón, V., and Torrent, J. (1998). Use and Limitations of Second-Derivative Diffuse Reflectance Spectroscopy in the Visible to Near-Infrared Range to Identify and Quantify Fe Oxide Minerals in Soils. Clays Clay Miner. 46, 528-536. doi:10.1346/CCMN.1998.0460506

Hu, S., Chenglong, D., Appel, E., and Verosub, K. (2002). Environmental Magnetic Studies of Lacustrine Sediments. Chin. Sci Bull 47, 613-616. doi:10.1360/ 02 tb9141

Shukla, A., Mehrotra, R. C., Spicer, R. A., Spicer, T. E. V., and Kumar, M. (2014). Cool Equatorial Terrestrial Temperatures and the South Asian Monsoon in the Early Eocene: Evidence from the Gurha Mine, Rajasthan, India. Palaeogeogr. Palaeoclimatol. Palaeoecol. 412, 187-198. doi:10.1016/j.palaeo.2014.08.004

Singh, B., Pawar, J., Singh, Y. R., Singh, G., and Srivastava, A. (2010). Marine to continental Transition and Sequence Stratigraphy in a Paleogene Succession of the Western Himalayan Foreland Basin, India. Gondwana Geol. Mag. 25, 195-211.

Sisodia, M., and Singh, U. (2000). Depositional Environment and Hydrocarbon Prospects of the Barmer Basin, Rajasthan, India. Nafta (Zagreb) 51, 309-326.

Smith, S. Y., Manchester, S. R., Samant, B., Mohabey, D. M., Wheeler, E., Baas, P., et al. (2015). Integrating Paleobotanical, Paleosol, and Stratigraphic Data to Study Critical Transitions: A Case Study from The Late Cretaceous-Paleocene of India. Paleontol. Soc. Pap. 21, 137-166. doi:10.1017/S1089332600002990

Snowball, I., and Thompson, R. (1990). A mineral Magnetic Study of Holocene Sedimentation in Lough Catherine, Northern Ireland. Boreas 19, 127-146. doi:10.1111/j.1502-3885.1990.tb00574.x

Spicer, R. A., Herman, A. B., Liao, W., Spicer, T. E. V., Kodrul, T. M., Yang, J., et al. (2014). Cool Tropics in the Middle Eocene: Evidence from the Changchang flora, Hainan Island, China. Palaeogeogr. Palaeoclimatol. Palaeoecol. 412, 1-16. doi:10.1016/j.palaeo.2014.07.011

Spicer, R. A., Yang, J., Herman, A. B., Kodrul, T., Maslova, N., Spicer, T. E. V., et al. (2016). Asian Eocene Monsoons as Revealed by Leaf Architectural Signatures. Earth Planet. Sci. Lett. 449, 61-68. doi:10.1016/j.epsl.2016.05.036

Srivastava, R., and Kumar, K. (1996). Taphonomy and Palaeoenvironment of the Middle Eocene Rodent Localities of Northwestern Himalaya, India. Palaeogeogr. Palaeoclimatol. Palaeoecol. 122, 185-211. doi:10.1016/0031-0182(95)00090-9

Srivastava, R. (2011). Indian Upper Cretaceous-Tertiary Flora Before Collision of Indian Plate: A Reappraisal of central and Western Indian Flora. Mem. Geol. Soc. India. 77, 281-292.

Stöcklin, J. (1980). Geology of Nepal and its Regional Frame. J. Geol. Soc. 137, 1-34. doi:10.1144/gsigs.137.1.0001

Tauxe, L., Mullender, T. A. T., and Pick, T. (1996). Potbellies, Wasp-Waists, and Superparamagnetism in Magnetic Hysteresis. J. Geophys. Res. 101, 571-583. doi:10.1029/95JB03041

Thompson, R., and Oldfield, F. (1986). Environmental Magnetism. 1st ed.. London, United Kingdom: Springer Science \& Business Media. doi:10.1007/978-94-011-8036-8

Tokuoka, T., Takayassau, K., Yoshida, M., and Hisatomi, K. (1986). The Churia (Siwalik) Group of the Arung Khola, West Central Nepal. Mem. Fac. Sci. (Matsue: Shimane Univ.) 20, 135-210.
Torrent, J., and Barrón, V. (2002). Diffuse Reflectance Spectroscopy of Iron Oxides. Encycl. Surf. Colloid Sci. 1, 1438-1446.

Upreti, B. N. (1999). An Overview of the Stratigraphy and Tectonics of the Nepal Himalaya. J. Asian Earth Sci. 17, 577-606. doi:10.1016/S1367-9120(99)00047-4

Valdiya, K. S. (1980). Geology of Kumaun Lesser Himalaya. Dehradun: Wadia Institute of Himalayan Geology.

van der Beek, P., Robert, X., Mugnier, J.-L., Bernet, M., Huyghe, P., and Labrin, E. (2006). Late Miocene - Recent Exhumation of the central Himalaya and Recycling in the Foreland basin Assessed by Apatite Fission-Track Thermochronology of Siwalik Sediments, Nepal. Basin Res. 18, 413-434. doi:10.1111/j.1365-2117.2006.00305.x

Verosub, K. L., and Roberts, A. P. (1995). Environmental Magnetism: Past, Present, and Future. J. Geophys. Res. 100, 2175-2192. doi:10.1029/94JB02713

Wallace-Dudley, K., and Leckie, D. (1993). The Lower Kaskapau Formation (Cenomanian): A Multiple-Frequency, Retrogradational Shelf System, Alberta, Canada. AAPG Bull. 77, 414-435. doi:10.1306/BDFF8C2C-171811D7-8645000102C1865D

Wells, N. A., and Gingerich, P. D. (1987). Paleoenvironmental Interpretation of Paleogene Strata Near Kotli, Azad Kashmir, Northeastern Pakistan. Kashmir J. Geol. 5, 23-41.

White, N. M., Parrish, R. R., Bickle, M. J., Najman, Y. M. R., Burbank, D., and Maithani, A. (2001). Metamorphism and Exhumation of the NW Himalaya Constrained by U-Th- $\mathrm{Pb}$ Analyses of Detrital Monazite Grains from Early Foreland basin Sediments. J. Geol. Soc. 158, 625-635. doi:10.1144/ jgs.158.4.625

Wignall, P. B. (1991). Model for Transgressive Black Shales?. Geol 19, 167-170. doi:10.1130/0091-7613(1991)019<0167:MFTBS >2.3.CO;2

Willis, B., Bhattacharya, J., Gabel, S., and White, C. (1999). Architecture of a TideInfluenced River delta in the Frontier Formation of central Wyoming, USA. Sedimentology 46, 667-688. doi:10.1046/j.1365-3091.1999.00239.x

Wright, V., and Burchette, T. (1996). "Shallow-water Carbonate Environments, Sedimentary Environments: Processes, Facies and Stratigraphy,". Editor HG Reading (Oxford: Blackwell Sciences), 325-394.

Yin, A., and Harrison, T. M. (2000). Geologic Evolution of the Himalayan-Tibetan Orogen. Annu. Rev. Earth Planet. Sci. 28, 211-280. doi:10.1146/ annurev.earth.28.1.211

Yin, A. (2006). Cenozoic Tectonic Evolution of the Himalayan Orogen as Constrained by Along-Strike Variation of Structural Geometry, Exhumation History, and Foreland Sedimentation. Earth-Sci. Rev. 76, 1-131. doi:10.1016/ j.earscirev.2005.05.004

Yoshida, M., and Sakai, H. (1984). Some Observations on the Paleomagnetism of Tansen Group, West central Nepal. J. Nepal Geol. Soc. 4, 53-61.

Yoshida, M., Khan, I. H., and Ahmad, M. N. (1998). Remanent Magnetization of Oolitic Ironstone Beds, Hazara Area, Lesser Himalayan Thrust Zone, Northern Pakistan: Its Acquisition, Timing, and Paleoenvironmental Implications. Earth Planet. Sp 50, 733-744. doi:10.1186/BF03352166

Zan, J., Kang, J., Yan, M., Fang, X., Li, X., Guan, C., et al. (2018). A Pedogenic Model for the Magnetic Enhancement of Late Miocene Fluvial-Lacustrine Sediments from the Xining Basin, NE Tibetan Plateau. J. Geophys. Res. Solid Earth 123, 6176-6194. doi:10.1029/2018JB016064

Conflict of Interest: The authors declare that the research was conducted in the absence of any commercial or financial relationships that could be construed as a potential conflict of interest.

Publisher's Note: All claims expressed in this article are solely those of the authors and do not necessarily represent those of their affiliated organizations, or those of the publisher, the editors and the reviewers. Any product that may be evaluated in this article, or claim that may be made by its manufacturer, is not guaranteed or endorsed by the publisher.

Copyright $\odot 2021$ Khatri, Zhang, Fang, Meng, Zhang, Zhang and Paudayal. This is an open-access article distributed under the terms of the Creative Commons Attribution License (CC BY). The use, distribution or reproduction in other forums is permitted, provided the original author(s) and the copyright owner(s) are credited and that the original publication in this journal is cited, in accordance with accepted academic practice. No use, distribution or reproduction is permitted which does not comply with these terms. 